\title{
1 Climatic variability during the last millennium in Western Iceland from lake sediment
}

2 records

3

4 Naomi Holmes ${ }^{\mathrm{a}}$, Peter G. Langdon ${ }^{\mathrm{b} *}$, Chris J. Caseldine ${ }^{c}$, Stefan Wastegård ${ }^{\mathrm{d}}$, Melanie J. Leng ${ }^{\mathrm{e}, \mathrm{f}}$, Ian W.

5 Croudace $^{\mathrm{g}}$ and Siwan M. Davies ${ }^{\mathrm{h}}$

6

7 a Department of the Natural and Built Environment, Sheffield Hallam University, Sheffield, S1 1WB,

8 UK

$9 \quad{ }^{b}$ Geography and Environment, University of Southampton, Southampton, SO17 1BJ, UK

$10{ }^{c}$ Geography, Penryn Campus, University of Exeter, Penryn, Cornwall, TR10 9FE, UK

11 dDepartment of Physical Geography, Stockholm University, SE-106 91 Stockholm, Sweden

$12{ }^{\mathrm{e} C e n t r e}$ for Environmental Geochemistry, School of Geography, University of Nottingham,

13 Nottingham, NG7 2RD, UK

$14{ }^{f}$ NERC Isotope Geosciences Facilities, British Geological Survey, Keyworth, Nottingham, NG12 5GG,

15 UK

16 gOcean and Earth Science, University of Southampton, National Oceanography Centre Southampton,

17 European Way, Southampton, SO14 3ZH, UK

18 hepartment of Geography, College of Science, Swansea University, Singleton Park, Swansea, SA2

$198 \mathrm{PP}, \mathrm{UK}$

$20 *$ *orresponding author 


\section{Abstract}

The aim of this research was to create a decadal scale terrestrial quantitative palaeoclimate record for NW Iceland from lake sediments for the last millennium. Geochemical, stable isotope and chironomid reconstructions were obtained from a lake sequence constrained by tephra deposits on the Snæfellsnes peninsula, W Iceland. Obtaining a quantitative record proved problematic, but the qualitative chironomid record showed clear trends associated with past summer temperatures, and the sedimentological records provided evidence for past changes in precipitation, mediated through catchment soil inwash. When the full range of chronological uncertainty is considered, four clear phases of climatic conditions were identified: (1) a relatively warm phase between AD 1020 - 1310; (2) a relatively stable period between $A D 1310$ and AD 1510, cooler than the preceding period, but still notably warmer that the second half of the millennium; (3) a consistent reduction of temperatures between AD 1560 - 1810, with the coolest period between AD 1680-1810; (4) AD 1840 - 2000 has temperatures mainly warmer than in the preceding two centuries, with a rising trend and increased variability from c. AD 1900 onwards. The reconstructions show clearly that the first half of the millennium experienced warmer climatic conditions than the second half, with a return to the warmer climate only occurring in the last c. 100 years. Much of the variability of the chironomid record can be linked to changes in the North Atlantic Oscillation (NAO). The reconstructions presented can track low frequency and long-term trends effectively and consistently but high resolution and calibrated quantitative records remain more of a challenge - not just in finding optimal sedimentary deposits, but also in finding the most reliable proxy. It is this that presents the real challenge for Holocene climate reconstruction from this key area of the North Atlantic. 
Understanding spatial variability in palaeoclimatic reconstruction relies heavily on high resolution quantitative data provided from climate proxies. Because of the importance of the sensitivity of the arctic and sub-arctic to climate change there have been attempts to derive such reconstructions for the North Atlantic (Kaufman et al., 2009) and a number of sites in Iceland have been examined for their palaeolimnological records to potentially be used for such reconstructions (Axford et al., 2009; 2011; Geirsdóttir et al., 2009a; Langdon et al., 2011; Larsen et al., 2011, 2012). Typically it has proved problematic to calibrate Icelandic proxy records into a quantitative temperature record. For example a biogenic silica (BSi) record for the last 2000 years from the Icelandic site Haukadalsvatn has been shown to be a proxy for spring/summer conditions related to diatom productivity (Geirsdóttir et al., 2009b), but it did not prove possible to calibrate this quantitatively. At other lakes in Iceland attempts have been made to provide quantitative data utilising chironomid-inferred July temperatures based on the Icelandic chironomid training set (Axford et al., 2007; Langdon et al., 2008, Holmes et al., 2011), and a multi-decadal scale summer temperature record now exists for NW Iceland since AD 1650 (Langdon et al., 2011). Longer records do exist, but at lower resolution (centennial scale) and quantification has relied on DCA axis related temperature correlations (Axford et al., 2009) or using a Norwegian chironomid training set (Caseldine et al., 2003). Palaeolimnological approaches have therefore yet to provide consistent high-resolution quantitative terrestrial temperature records for the later Holocene in Iceland. There are a number of potential reasons for this:

(1) It is still unclear what sort of lake provides the best sediments for analysis in Iceland. Axford et al. (2009) have highlighted difficulties with large, deep lakes, especially for chironomid based temperature reconstruction approaches. Additionally, with any transfer function approach, there may be problems associated with secondary gradients (Juggins 2013), and hence caution is required in interpreting such reconstructions;

(2) Altitude may also be significant as the only Icelandic lake to produce chironomid based proxy results that correlate well with instrumental data, Mýfluguvatn, lies at $435 \mathrm{~m}$ above sea level (Langdon et al., 2011), and may well indicate that it is only at higher altitudes that climate changes will be significant enough to register in the faunal or sedimentary records. If this is the case then these lakes are likely to have relatively low sedimentation rates, and relatively low concentrations of potential proxies;

(3) Post Settlement ( AD 874) human influences on catchments, particularly soil erosion (McGovern et al., 2007), have been shown to affect chironomid assemblages within lakes 
(Lawson et al., 2007). Careful site selection, limiting the effects of human settlements, is important, particularly over the instrumental (calibration) period;

(4) There are as yet few proxies that have the potential to provide quantitative palaeoclimatic data. \% BSi has been interpreted as responding to local diatom productivity, which in turn is a function of climate, especially the duration of the ice-free season and spring temperatures (Geirsdóttir et al., 2009b; Striberger et al., 2012), but does not yet provide a quantitative signal. Similarly at Haukadalsvatn Geirsdóttir et al. (2009b) have shown that the sediment total organic carbon content (TOC) is strongly related to soil erosion and summer temperatures, but again not yet quantified. Chironomid-based calibration models can be used to provide chironomid-inferred temperature (C-IT) reconstructions (Langdon et al., 2008; Axford et al., 2007, 2009; Holmes et al., 2011) although they have not yet been widely tested at a variety of locations and lake types in Iceland;

(5) Chronology and sedimentation rate still play an important role in determining whether lake sediments can provide high resolution, robust data. Radiocarbon dating has been found to present problems in Iceland (Geirsdóttir et al., 2009b), ideally requiring a sound tephrochronology for age-depth profiles, possibly with assistance from palaeomagnetism (Ólafsdóttir et al., 2013).

Multiproxy, tephrochronologically constrained data presented here from Baulárvallavatn, studied as part of the EU-funded MILLENNIUM project, attempt to address the issues raised above. Owing to the location of Iceland in such an important position for the climate of the North Atlantic and the development of high quality marine records that are now available for the region (e.g., Massé et al., 2008; Ólafsdóttir et al., 2010; Sicre et al., 2011; Cunningham et al. 2013) it is important to determine how best to provide the necessary terrestrial equivalent and the results from this study reveal both the potential and problems of such work.

\section{Study Site}

Baulárvallavatn $\left(64^{\circ} 54^{\prime} \mathrm{N}, 22^{\circ} 53^{\prime} \mathrm{W}\right.$ ) in western Iceland (Figure 1a) was selected after preliminary examination of a range of lakes in the region to provide a high-resolution palaeoclimate record for the last 1000 years. The site was chosen because it is located only $20 \mathrm{~km}$ from the meteorological station at Stykkishólmur which has an observational record dating back to $A D$ 1845, extended to $A D$ 1823 using data from Reykjavík (available at http://www.vedur.is), providing a good opportunity to validate the proxy record over the observational period. Lakes closer to the station were considered to be more affected by human activity and to likely be less sensitive to temperature variations lying 
124 close to sea level. Baulárvallavatn, located at $193 \mathrm{~m}$ above sea level, was considered more likely to 125 be temperature sensitive, whilst retaining a reasonable sedimentation rate. Additional site 126 description and data are detailed in Holmes et al. (2009).

\section{Materials and Methods}

129 Fieldwork

130 A bathymetric profiling of the lake (Figure $1 \mathrm{~b}$ ) was produced by traversing the lake in a boat with a 131 depth sounder and portable GPS. A $70 \mathrm{~cm}$ core (BAUL) was obtained from a water depth of $30 \mathrm{~m}$ 132 using a UWITEC corer. The core was not taken from the deepest part of the lake $(46 \mathrm{~m})$ but was from 133 a relatively flat bottomed part of the lake (Figure $1 b$ ), as in the deeper areas the lake bottom shelved 134 steeply and potential problems exist with using the Icelandic temperature transfer function on deep $135\left(z_{\max }>30 \mathrm{~m}\right)$ sites (Axford et al., 2009). The core was returned to the laboratory where it was stored

136 at $4{ }^{\circ} \mathrm{C}$. Other replicate cores were taken from across the basin, and key stratigraphic changes and/or 137 specific measured parameters are reported below.

\section{Sediment geochemistry}

140 On return to the laboratory the core was split in half and analysed using the Itrax micro-XRF core 141 scanner (Croudace et al., 2006) at the British Ocean Sediment Core Research Facility (National

142 Oceanography Centre, Southampton). These analyses provided X-radiographic images and down143 core elemental compositional variations at a $200 \mu \mathrm{m}$ resolution. The XRF data were acquired using a 144 Mo X-ray tube running at 30kV 30mA. A count time of 15 seconds per increment was used.

\section{Chronology}

147 Despite the well documented problems of radiocarbon dating in Icelandic lakes, primarily due to old 148 carbon entering the lake system through terrestrial and/or groundwater pathways, some pilot 149 radiocarbon analyses were attempted on BAUL. Due to a lack of terrestrial macrofossils within the 150 core five bulk sediment subsamples were sent to the Poznan Radiocarbon laboratory for dating, with one level, $47-47.5 \mathrm{~cm}$, also being analysed for the humic acid fraction. A water sample (taken in 2007) was also analysed for its radiocarbon content.

154 The uppermost samples were freeze dried and analysed for ${ }^{137} \mathrm{Cs}$ by gamma spectroscopy using a 155 well-type coaxial low background intrinsic germanium detector. ${ }^{137} \mathrm{Cs}$ was measured using the 660 $156 \mathrm{keV}$ gamma energy and counting was for $100 \mathrm{ksec}$ for each sample. The efficiency function of the detector was determined using an NPL (Teddington, UK) certified mixed gamma source. 
159 Tephra analyses can be a useful addition to developing chronological models in Iceland (e.g. Boygle 160 1999; Caseldine et al., 2006), although relatively large volumes of background ash levels can make identifying individual eruptions problematic. In western Iceland relatively few primary ashfalls have been identified (Thordarsson and Höskuldsson, 2008), which is unsurprising given the prevailing westerly winds and that all major volcanic centres, except Snæfellsjökull, are located to the east. Following visual and $\mathrm{x}$-ray inspection of the core, and XRF scanning a number of samples were selected for tephra analyses (cf. Kylander et al., 2012). These samples were sieved ( 80 and $25 \mu \mathrm{m}$ ) and processed using a heavy-liquid separation method (Turney, 1998) to isolate the $2.3-2.5 \mathrm{~g} / \mathrm{cm}^{3}$ and $>2.5 \mathrm{~g} / \mathrm{cm}^{3}$ fractions. Each fraction was prepared onto slides for geochemical analysis by electron microprobe analysis (EPMA). A Cameca SX-100 microprobe housed the University of Edinburgh was used for this work and the operating conditions followed those outlined in Hayward (2012). In order to derive a chronological model with estimated age uncertainties throughout the core the chronological information (coring date, ${ }^{137} \mathrm{Cs}$ peak and tephra dates) were input into the $\mathrm{R}$ package Bchron (Haslett and Parnell, 2008). Bchron (MCMC function, 100000 iterations) fits a compound Poisson-gamma distribution to the increments between the dated levels; these are then used to predict ages for depths through the core. The mean chronology was calculated and is the chronology that is used to plot the downcore data from Baulárvallavatn. The full range of chronological models (10000) provides us with chronological uncertainties for the whole core not usually afforded when using historical tephrochronology.

\section{Magnetic susceptibility}

180 The magnetic susceptibility of discrete samples ( $0.5 \mathrm{~cm}$ freeze dried samples) was measured using a

181 Bartington MS2 Susceptibility system (Dearing, 1994). Both low ( $\chi \mathrm{lf})$ and high ( $\chi \mathrm{hf}$ ) frequency mass magnetic susceptibility were measured, and percentage frequency dependent susceptibility ( $\chi f d \%)$ was calculated. nitrogen (\%TN) were determined on decarbonated samples using a Carlo Erba Elemental Analyser (NA 1500) attached to a VG Optima mass spectrometer and VG Triple Trap. $\delta^{13} \mathrm{C}_{\text {organic }}$ values were calculated to the VPDB scale using a within-laboratory standard (BROC) (replication precision of $\pm 0.12 \% ; 2 \sigma$ ). \%TOC and \%TN were determined with reference to an Acetanilide standard (replication precision $0.16 ; 2 \sigma$ ). These values were used to calculate weight $\mathrm{C} / \mathrm{N}$ ratios. 


\section{Diatom and modern water stable isotopes}

194 Samples for $\delta^{18} \mathrm{O}_{\text {diatom }}$ were prepared using a process of chemical digestion, differential settling, sieving and heavy liquid separation loosely based on Morley et al. (2004). Sediment samples were treated with $30 \% \mathrm{H}_{2} \mathrm{O}_{2}$ at $90^{\circ} \mathrm{C}$ until reactions ceased (to remove organic material), before using $5 \%$ $\mathrm{HCl}$ to eliminate any carbonates. Following differential settling, all samples were centrifuged in sodium polytungstate (3Na2WO49WO3.H2O) (SPT) heavy liquid, resulting in the separation and suspension of diatoms from the heavier detrital residue. The purified diatom samples were then sieved at $10 \mu \mathrm{m}$ and checked for purity using microscopy. Multiple cleans were required to ensure that all tephra shards were removed. Purified diatom samples were analysed for $\delta^{18} \mathrm{O}_{\text {diatom }}$ using the step-wise fluorination method outlined in Leng and Sloane (2008). The outer hydrous layer of the diatom, known to freely exchange isotopically with water (e.g. Juillet-Leclerc and Labeyrie, 1987), was removed in a pre-fluorination stage using $\mathrm{BrF}_{5}$ at low temperature. This was followed by a full reaction at high temperature to liberate oxygen that was then converted to $\mathrm{CO}_{2}$ (Clayton and Mayeda, 1963) and measured for $\delta^{18} \mathrm{O}_{\text {diatom }}$ using a MAT253 dual-inlet mass spectrometer. All $\delta^{18} \mathrm{O}$ values were converted to the VSMOW scale using the within-run laboratory standard BFCmod, and are reported here in per mil (\%o). Replication precision for $\delta^{18} \mathrm{O}$ is typically $+/-0.3 \%$ o

Oxygen isotope $\left(\delta^{18} \mathrm{O}\right)$ measurements on water samples were made using the $\mathrm{CO}_{2}$ equilibration method with an Isoprime 100 mass spectrometer plus Aquaprep device. Deuterium isotope (סD) measurements were made using an online $\mathrm{Cr}$ reduction method with a EuroPyrOH-3110 system coupled to a Micromass Isoprime mass spectrometer. Isotope measurements used internal standards calibrated against the international standards VSMOW2 and VSLAP2. Replication precisions are typically $+/-0.05 \%$ for $\delta^{18} \mathrm{O}$ and $+/-1.0 \%$ for $\delta \mathrm{D}$.

\section{Subfossil chironomids}

218 Samples were prepared for subfossil chironomid analysis using standard techniques (Brooks et al.,

219 2007) including ultrasound treatment (Lang et al., 2003). The head capsules were identified using

220 Hofmann (1971), Wiederholm (1983), Schmid (1993), Rieradevall and Brooks (2001) and Brooks et al.

221 (2007). The chironomid diagram was produced using C2 (Juggins, 2007). Principal components

222 analysis (PCA) was undertaken using Canoco (ter Braak and Smilauer, 2002) and both the Icelandic

223 chironomid-inferred July air temperature transfer function (Langdon et al., 2008) and a combined

224 Norwegian-Icelandic chironomid-inferred July air temperature transfer function (Holmes et al., 2011)

225 were applied to the downcore data using C2 (Juggins, 2007). Bchronproxyplot (Parnell and Haslett, 
2008) was used to produce inferred climate reconstructions showing the full range of chronological uncertainty.

\section{Results}

The X-radiographs generated images revealing clear millimetric and sub-millimetric layering (Figure 2). The distinct dark bands correspond to denser mineralogical layers that most likely indicate ash layers or in-wash events. The higher density of such layers may relate to composition and/or finer grain size. The identification of relative density variations of layers at medium to high resolution coupled with the elemental analytical capability permits the potential recognition of marker layers, which were investigated further to try and identify well defined tephra layers (see below). The elemental signatures of the layers seen implied that recognition is easiest with intermediate-acid igneous compositions (co-variation in $\mathrm{Si}, \mathrm{K}, \mathrm{Rb}$ and $\mathrm{Zr}$ ). Two tephras were identified, both from the $\mathrm{X}$ radiograph and clear peaks in $\mathrm{K}$ and $\mathrm{Zr}$, towards the base of the core, at depths of $55-56 \mathrm{~cm}$ and 66 $67 \mathrm{~cm}$ (Figure 2).

Other elemental signatures and ratios can typically be used to help identify variations in clastic input. For example, $\mathrm{Si} / \mathrm{Ti}$ are typically used to reflect clastic input associated with grain size variations (e.g. Chawchai et al, submitted), although other researchers have argued it can be a proxy for biological silica (BSi) (Johnson et al. 2011; Liu et al. 2013). Si has multiple roles in geochemical processes, being found in siliceous microfossils and mineral material. Given the large amount of mineral materials in Icelandic lake sediments, notably from (often reworked) basalts and related igneous material, the Itrax data was studied to see if we could see evidence for changes in clastic input, which may be driven by changes in precipitation. $\mathrm{Zr} / \mathrm{Rb}$ ratios were examined, as $\mathrm{Rb}$ is commonly associated with clay, while $\mathrm{Zr}$ is enriched in coarse silts, hence high $\mathrm{Zr} / \mathrm{Rb}$ reflect coarse particles (Schillereff et al. 2014). However, the dominant basaltic composition of sediment sources in the Baulárvallavatn catchment makes the use of geochemical proxies for environmental/precipitation changes (e.g. Si/Ti, $\mathrm{Zr} / \mathrm{Rb}$ ) difficult as the Itrax signals for $\mathrm{Si}$ and $\mathrm{Rb}$ are small (except where there is a contribution from more evolved ash-rich layers of intermediate to silicic composition). So in the current context the Itrax data (geochemistry and radiograph) aid the identification of tephras (especially intermediatesilicic), but elemental profiles do not indicate any clear variations that correlate with other proxies for environmental change. 
261 The ${ }^{137} \mathrm{Cs}$ analyses showed a clear peak in levels attributed to 1963 at $2.5 \mathrm{~cm}$ depth. Providing a longer chronology for the sediment sequence proved to be problematic. The series of radiocarbon dates showed no regular change through time with all dates providing values between $2600-2100$ ${ }^{14} \mathrm{C}$ yr BP (Table 1). A radiocarbon determination of modern lake water (sampled in 2007) showed considerable input of old carbon from the eroding soils in the catchment and there is little reason to believe that such an ageing effect will not have occurred consistently over the last millennium.

Eight samples were selected for tephra analyses. The two visible tephra layers (55-56 cm and 66-67 cm) were geochemically identified as the Landnám (AD871 \pm 2 ; Grönvold et al., 1995) and Sn-1 (1780 $\pm 35 \mathrm{BP}$; Larsen et al., 2002) tephras (Figure 3a). Both the basaltic and the rhyolitic component of the Landnám tephra were present. Glass shards from the remaining tephra-rich horizons were geochemically identified as deriving from the Hekla, Snæfellsjökull, Torfajökull, Katla and Veiðivötn volcanic systems (Table 2). The density fractions were dominated by silicic shards ( $\mathrm{SiO}_{2}>63 \%: 2.3-2.5$ $\left.\mathrm{g} / \mathrm{cm}^{3}\right)$ and basaltic shards $\left(\mathrm{SiO}_{2} 45-52 \%:>2.5 \mathrm{~g} / \mathrm{cm}^{3}\right)$. Intermediate shards $\left(53-62 \% \mathrm{SiO}_{2}\right)$ were found in both density fractions. The silicic samples were dominated by shards from Torfajökull (To) and Snæfellsjökull (Sn). These are interpreted as reworked shards from the Landnám and Sn-1 eruptions (and possibly Sn-2 and Sn-3; Jóhannesson et al., 1981) since no younger tephras from these systems are known (Haflidason et al 2000). Silicic shards from Katla (SILK) occur in some samples. These shards are also interpreted as reworked and can either derive from the youngest silicic eruption of Katla, SILK-YN which is dated to $1676 \pm 12$ BP or the older SILK-N4 (Larsen et al., 2001, Larsen and Eiríksson 2008). These eruptions had lobes extending to the northwest and it is possible that some shards may have reached western Iceland and the catchment of Baulárvallavatn. Intermediate and silicic shards from Hekla occur in most samples, and are especially abundant at 10-11 and 23-24 cm. However, given the abundance of reworked shards from other older silicic eruptions, a significant part of the Hekla shards can be expected to be reworked, in particular the highly silicic shards $\left(\mathrm{SiO}_{2}\right.$ $>65 \%$ ). Basaltic tephra from all the main basaltic volcanic systems occur in the samples, i.e. Grímsvötn, Veidivötn and Katla. However, the dominant basaltic component has high $\mathrm{Al}_{2} \mathrm{O}_{3}$ (c. $15-16$ wt \%) and $\mathrm{K}_{2} \mathrm{O}$ (c. 0.8-1.2 wt \%) content and has affinities to basaltic lavas from the Snæfellsnes Volcanic Zone, mostly those of the Ljosufjoll system (Kokfelt et al, 2009; Steinthorsson et al. 1985 and unpublished data). It could, however, also originate from the older hyaloclastite formations in the vicinity of the lake and be blown or washed in to the lake. 
293 All analyses are listed in Table 2 and details can be found in the Supplementary Material. The tephra-

294 based age model assumes that some of the analysed tephra shards are primary and represent true 295 isochrons in the sediment. We are aware, however, that the majority of the shards are likely reworked by catchment processes. For example, several of the shards with Hekla affinity could be reworked from prehistoric eruptions which had a westward distribution, e.g. Hekla-B and Hekla-C

298 (Larsen and Eíriksson, 2008). Although each sample contained a mixture of shards thought to

299 originate from different volcanic centres, we pinpoint the specific volcanic eruption based on the

300 abundance of shards and the known dispersal patterns of historical eruptions in Iceland. For

301 example, two samples $(3-4 \mathrm{~cm}$ and $14-15 \mathrm{~cm}$ ) contain relatively large amounts of shards from

302 Veiðivötn, but despite these relatively high numbers, we are not aware of any historical eruptions

303 from this centre being dispersed towards northwest Iceland, and hence interpret them as reworked

304 shards from the basaltic part of the Landnám tephra. The samples at 3-4 cm contain a numbers of

305 basaltic grains from Katla. Tephra was dispersed widely from the eruption of Katla in 1918 including

306 one lobe reaching Snæfellsnes (Larsen et al., 2014) and we suggest that the shards in the 3-4 cm

307 sample derive from that eruption. The sample at 10-11 cm has abundant tephra from several

308 volcanic systems. Silicic shards from Hekla, however, are one of the most abundant components

309 within this sample and it is possible that some of these shards $\left(\mathrm{SiO}_{2}<65 \%\right)$ derive from the relatively

310 large eruption in 1766. Tephra-fall was reported from north and northwest Iceland but the Hekla

3111766 deposit has as yet, not been found on Snæfellsnes (cf. Larsen et al., 2014). Tephra from the

312 eruption of Katla in 1721 reached western Iceland (Larsen et al., 2014) and we suggest that the few

313 Katla shards in the $14-15 \mathrm{~cm}$ may relate to this event. The same sample also contains a reasonable

314 number of shards from the Hekla volcanic system which may be derived from Hekla-1693 event. The

315 Hekla-1693 tephra was carried towards the northwest and has recently been confirmed in lake sites

316 in the Western fjords (Langdon et al., 2011). The sample at $23-24 \mathrm{~cm}$ is more difficult to assign to a

317 certain eruption. More than half of the analyses suggest an origin in the Hekla system and indeed

318 several of the analyses show similarities with the Hekla 1510/Loch Portain B tephra, found in

319 Scotland and Ireland (Figure 3b; Dugmore et al., 1995; Pilcher et al., 1996). Reports from Iceland,

320 however, are scarce (Larsen et al., 2014) and indicate a main dispersal axis towards the southwest.

321 Nonetheless, given the good matches identified in Figure 3b, we use Hekla 1510 in our age model

322 (Table 2). Only a few analyses are available from $29-30 \mathrm{~cm}$ and the shards with Hekla affinity do not

323 allow a secure correlation with any of the historic eruptions of Hekla. It is possible, however, that the

324 Hekla 1341 eruption reached the area since a tephra fall was reported in west and northwest Iceland 325 at this time (Thorarinsson 1967). We are unable to pinpoint a volcanic eruption for sample $33-34 \mathrm{~cm}$. 
327 The tephra dates (Table 2) were used alongside the ${ }^{137} \mathrm{Cs}$ data and coring date to produce a 328 chronological model using Bchron, which is presented in Figure 4. Given the uncertainties associated with which Hekla eruption might be represented by the samples at 23-24 cm and 29-30 $\mathrm{cm}$ (as noted above), three age models were developed, taking into account the maximum uncertainties (i.e. oldest and youngest possible tephras for the less certain Hekla levels). The most parsimonious model is shown in Figure 4, with Hekla 1510 assigned to 23-24 cm, and Hekla 1341 assigned to $29-30 \mathrm{~cm}$. This approach allows the estimation of chronological uncertainty through the core; chronological uncertainty is smaller closer to the tephra layers where the chronology is constrained by the most confident tephra matches. There is a reasonably constant sedimentation rate of approximately $0.05 \mathrm{~cm} \mathrm{yr}^{-1}$ during the past 1000 years. Although beyond the main timescale focus of this study it can be seen that prior to Settlement the sedimentation rate was lower (c. 0.02

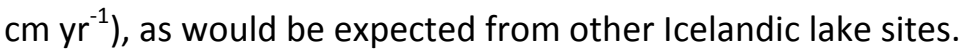
The \%TOC, $\mathrm{C} / \mathrm{N}, \delta^{13} \mathrm{C}$ and magnetic susceptibility data (Figure 5) show clear changes through the record. Isolated spikes (low \%TOC values at AD 870 and AD 1341) reflect the dominant input of isolated tephra horizons from single eruptions; details also identified from the Itrax elemental data (cf. Kylander et al., 2012). Apart from the effect of the Sn-1 tephra (c. AD 170) prior to Settlement the sedimentary records are relatively uniform implying little variability in catchment dynamics through time, with a $\delta^{13} \mathrm{C}$ value around $-26 \%$, \%TOC of around $3 \%$ and $\mathrm{C} / \mathrm{N}$ of c. 9. After Settlement all these proxies show significant variations with a trend to increasing $\% \mathrm{TOC}$, lower $\delta^{13} \mathrm{C}$, reaching <$27 \%$ at the surface, and $\mathrm{C} / \mathrm{N}$ values of between 10 and 12 , though these decrease to around 9.5 at the surface. Changes are less apparent in the magnetic susceptibility record with greater variability before the last millennium, but slightly higher low frequency susceptibility values following Settlement. A short lived peak in frequency dependent susceptibility c. AD 1210 stands out, which also corresponds with an increased peak in \%TOC, $\mathrm{C} / \mathrm{N}$ and increase in $\delta^{13} \mathrm{C}$. Waters for isotope analysis were sampled soon after ice out (April/May 2007), which likely reflects winter precipitation, and also from the preceding summer, July 2006, to compare any seasonal differences. The winter waters had lower $\delta^{18} \mathrm{O}$ compared to summer, and Baulárvallavatn and the other nearby lakes all plot along the global meteoric water line (GMWL) (Figure 6), indicating the lake waters represent seasonal variation in precipitation and a sub-annual lake water residence time (St Amour et al., 2010). Two of the lakes, Svínavatn and Saurarvatn, have summer isotope 
361

362

363

364

365

366

367

368

369

370

371

372

373

374

375

376

377

378

379

380

381

382

383

384

385

386

387

388

389

390

391

392

393

394

compositions that define a local evaporation line (LEL). Both these lakes are smaller and shallower than Baulárvallavatn, suggesting that these lakes evaporate in the summer but are recharged in the winter.

The diatom $\delta^{18} \mathrm{O}$ data (Figure 5f) cover the period AD 100-1300. No samples were analysed postAD1300 as the background tephra concentrations were too great, prohibiting clean preparations from being obtained, despite several attempts. The data pre-AD 1200 vary between +28.4 to $+32 \%$, with a mean value of $+29.7 \%$. A peak value of $+32 \%$ is centred on $A D 295$, with low values (around $+29 \%$ ) centred pre-AD 200, and around AD 540, AD 930, and AD 1140. Post-AD 1200, there is a short-lived increase to $+40 \%$ around $A D 1205$ before a decrease to $+26 \%$, the lowest value measured in the core, c. AD 1295. The extreme high value of $+40 \%$ was replicated in multiple sample analyses and compared with spikes in other sedimentological proxies (Figure 5). The isotopic composition of present day waters $\left(\delta^{18} \mathrm{O}, \delta \mathrm{D}\right)$ was measured from Baulárvallavatn and nearby lakes (Figure 6).

\section{Chironomid stratigraphy}

Forty six chironomid taxa were identified in the Baulárvallavatn core; the percentage diagram (Figure 7) shows selected taxa only. The chironomid assemblage is dominated by Heterotrissocladius grimshawi-type (between 24-73\%) with Psectrocladius sordidellus-type (2-32\%), Chironomus anthracinus-type (0-32\%), Paracladopelma (0-18\%), Eukiefferiella (0-17\%) and Micropsectra (0-14\%) the next most abundant taxa. These taxa commonly occur in high levels in many other Icelandic lakes (Langdon et al., 2008). The majority of the chironomid taxa present occur throughout the core and although there are no major changes in terms of one taxon replacing another, there are some clear trends and oscillations in certain taxa throughout the core. The base of the sequence is dominated by relatively high abundances (although variable) of thermophilous taxa such as $C$. anthracinus-type and $P$. sordidellus-type that lasts until the early 1300 s. There is a noticeable change in chironomid assemblage c. AD 1450-1520, with an increase in Chaetocladius. The period from late $A D 1500$ to mid AD 1800 has a relative increase in Diamesa, which typically represent cooler conditions. Head capsule concentration ranged between 19 and 187 head capsules $\mathrm{g}^{-1}$, with the peak concentration of 187 head capsules $\mathrm{g}^{-1}$ occurring at c. AD 1220.

\section{Chironomid-inferred temperature reconstructions}

The most commonly used method to produce a temperature reconstruction from downcore data is to apply a transfer function developed using a modern surface sample training set (e.g., Caseldine et 

temperature reconstruction produced by applying the Icelandic transfer function (Langdon et al., 2008) to the Baulárvallavatn data (Figure 7) shows a range of reconstructed temperatures of $2.5^{\circ} \mathrm{C}$ (maximum $=9.7^{\circ} \mathrm{C}$; minimum $=7.2^{\circ} \mathrm{C}$ ) during the past 1000 years. The chironomid samples covering the period $1961-1990$ infer a mean July air temperature of $8.59^{\circ} \mathrm{C}$. When this is compared with the modelled mean July air temperature of $9.62^{\circ} \mathrm{C}$ from 1961-1990 (Björnsson et al. 2003) it is clear there is an under-prediction of over $1{ }^{\circ} \mathrm{C}$ (just within the model RMSEP of $1.1^{\circ} \mathrm{C}$ ). A combined Norwegian-Icelandic transfer function (Holmes et al., 2011) was also applied to the data (Figure 7), as this model may produce more realistic temperature reconstruction (Holmes et al., 2011). The results from this approach were similar to those produced using the Icelandic transfer function, though the range of reconstructed temperatures was slightly smaller $\left(2.2^{\circ} \mathrm{C}\right)$. When compared to the Stykkishólmur instrumental temperature data (corrected for altitude) both the chironomidinferred temperature reconstructions produce values which under-predict by between $0.5^{\circ} \mathrm{C}$ and 1 ${ }^{\circ} \mathrm{C}$. It should be remembered that the chronological uncertainty precludes validation of the chironomid data against the instrumental data, and therefore only a visual comparison is used here. It is clear from this approach that the trends and pattern of the C-IT reconstructions are not similar to the instrumental data. Over the whole period studied both the chironomid-inferred temperature reconstructions suggest that the second half of the millennium had higher temperatures, with the warmest period occurring between c. AD 1600-1840 and the warmest temperature reached c. AD 1800. This is contrary to what is known about the climate of this time from other data sources; as a result the chironomid-inferred temperature reconstructions are not interpreted any further (cf. Axford et al., 2009) and possible reasons for this are discussed below.

417

\section{Ordination of the chironomid data}

419 Detrended correspondence analysis (DCA) revealed a gradient of 0.98 standard deviation units 420 resulting in the linear treatment of the data in further analyses. PCA was carried out and PCA axis 1 421 scores are shown in Figures 7 and 8. The PCA axis 1 scores show a remarkable similarity to other 422 palaeoclimatic proxy data covering the same time period (Figure 9) and have been interpreted as 423 providing a palaeoclimatic reconstruction with higher PCA axis 1 scores reflecting warmer 424 temperatures and lower PCA axis 1 scores reflecting cooler temperatures (see below for discussion).

426 Figure 8 was produced using Bchronproxyplot in Bchron (Haslett and Parnell, 2008) and shows the 427 PCA axis 1 scores plotted using a sample of 1000 chronologies (grey lines) produced for the core. The PCA axis 1 scores are also plotted against the mean chronology (black line); using this, the 
highest PCA axis 1 score occurred c. AD 1060 while the lowest score occurred c. AD 1780. It can be seen, when taking into consideration chronological uncertainty, that the period c. AD 1000 to c. AD 1550 has higher PCA axis 1 scores (and therefore was warmer) than the period c. AD 1550 to AD 2006. Looking at the grey plots it seems that the latter period has more variability, though this is possibly due to tighter chronological constraint during this time. It is also clear from this diagram that using data such as these (e.g. non-varved, non-annually resolved data) to perform calibration against instrumental data would be unwise, therefore this has not been attempted as part of this study. A better chronologically constrained core would be needed in order to do this.

437

\section{Discussion}

The sediment record and lake history

440 By combining the \%TOC, $\mathrm{C} / \mathrm{N}, \delta^{13} \mathrm{C}$ and sedimentation rate results it is possible to infer the changing nature of sedimentation into the lake over the last millennium. Prior to Settlement ( AD 874) sedimentation was low at $0.02 \mathrm{~cm} \mathrm{yr}^{-1}$ and \%TOC reflects lake productivity as seen in $\mathrm{C} / \mathrm{N}$ values below 10 (algal material), and $\delta^{13} \mathrm{C}$ around $-26 \%$ (typical of aquatic plants, Figure 5). Following Settlement the rate of sedimentation increased by a factor of 2.5 to $0.05 \mathrm{~cm} \mathrm{yr}^{-1}$, with a rapid doubling in \%TOC and a change in $\mathrm{C} / \mathrm{N}$ to over 10 (suggesting a terrestrial component). From around $A D 1400$ there was a further gradual rise in $C / N$ peaking at the end of the $19^{\text {th }}$ century, mirroring a change in $\delta^{13} \mathrm{C}$ to $-27 \%$ (values typical of terrestrial plants). The $\% \mathrm{TOC}, \mathrm{C} / \mathrm{N}$ and $\delta^{13} \mathrm{C}$ records correlate well (Figure 9). As \%TOC increases, so does $\mathrm{C} / \mathrm{N}$, indicating that the increase in \%TOC is driven by in-wash of terrestrial organic matter (higher $\mathrm{C} / \mathrm{N}$ than algae) and hence old soil carbon and terrestrial plant fragments were likely continuously added to the lake system (cf. Axford et al., 2009; Gathorne-Hardy et al., 2009; Geirsdóttir et al., 2009b). The lower $\delta^{13} \mathrm{C}$ with increased \%TOC corroborates this interpretation (Langdon et al. 2010). The alternative explanation, of increasing algal productivity, would have led to increases in $\delta^{13} \mathrm{C}$ (not decreases), as algae preferentially utilise ${ }^{12} \mathrm{C}$ (Meyers and Teranes, 2001). Interestingly, it is this latter relationship that Geirsdóttir et al. (2009b) found at Haukadalsvatn, with an associated increase in BSi, suggesting that the lake had undergone a phase of enhanced productivity, perhaps stimulated through the input of increased organic matter.

The ability of quite large plant remains to be deposited across the lake can be observed during spring melt when rivers in flood and small debris flows extend over the remaining ice cover. It seems likely that isolated peaks in $\delta^{13} \mathrm{C}$ could indicate extreme winter/spring flood or flow events that move material directly onto ice over the deeper parts of the lake, as a suite of cores from across the lake 
463

464

465

466

467

468

469

470

471

472

473

474

475

476

477

478

479

480

481

482

483

484

485

486

487

488

489

490

491

492

493

494

495

496

showed occasional lenses of poorly humified plant debris. The importance of redeposited C in the lake, both as particulate and dissolved material is evident from the radiocarbon analyses. The lake water currently has a radiocarbon age of almost 3500 years and this, coupled with redeposited plant and/or soil remains from the catchment, gives the relatively uniform set of ages for the lake sediment. Sufficient macrofossil remains for dating were not available from the selected core, although in an adjacent core a date of $2120 \pm 30{ }^{14} \mathrm{C}$ BP was obtained from moss remains near the base of the core, a date that fits well with the depth and age of the tephra Sn-1 in the sampled core. Nonetheless, given the evidence of increased erosion from the catchment there is no guarantee that ages from terrestrial macrofossils will be contemporaneous between the date of inwash and the material being transported.

The increased soil erosion through the last millennium at Baulárvallavatn (increase in \%TOC etc.) is most likely due to one, or both, of two processes. Settlements at lower altitudes typically introduced sufficient grazing around the lake to initiate severe and persistent soil erosion (e.g. Simpson et al., 2004; Lawson et al., 2007), and this is likely a background effect. Superimposed on this are changes in climate, as cooler dry summers can reduce vegetation cover, enhancing aeolian erosion and transport of organic matter into the lake (Geirsdóttir et al., 2009b). Increases in \%TOC can thus be interpreted as moving towards cooler summers, with dry windy winters, as exemplified by Geirsdóttir et al. (2009b). Following this line of argument, it seems likely that significant shifts in the $\delta^{13} \mathrm{C}$ record, as at c. AD 1240 and AD 1550, may well represent a climate driven signal, with the highest \%TOC and $\mathrm{C} / \mathrm{N}$ and the lowest $\delta^{13} \mathrm{C}$ (outside the most recent sediments) being found around AD 1750, a period interpreted as particularly cold (see later discussion) (Figure 9). The emerging interpretation is thus of a lake subject to enhanced organic input derived from the surrounding catchment over the last millennium, in contrast to preceding centuries, which most likely reflects in part an anthropogenic signal, but crucially, a strong climate signal through increased erosion of a less resilient surface soil.

\section{Climate variability of the last 1000 years}

The $\delta^{18} \mathrm{O}_{\text {diatom }}$ record (Figures 5 and 9 ) is interpreted in terms of changes in seasonal precipitation following the arguments outlined in Rosqvist et al. (2013), as Baulárvallavatn is a hydrologically open lake (low residence time, non-evaporative). When cool Arctic air masses dominate, lake waters have low $\delta^{18} \mathrm{O}$, whereas higher $\delta^{18} \mathrm{O}$ would result from southwesterly derived north Atlantic air masses (GNIP database, 2014). Rosqvist et al. (2013) argue that for their $\delta^{18} \mathrm{O}_{\text {diatom }}$ records from Sweden, temperature impacts on the stable isotope record are likely negligible, as the summer temperature 
497 changes over the last 1000 years are in the order of $1{ }^{\circ} \mathrm{C}$ (Esper et al., 2012). Given the net effect of 498 an increased condensation temperature is in the order of $+0.5 \% /{ }^{\circ} \mathrm{C}$ (following Rosqvist et al., 2013), 499 and the amplitude of the $\delta^{18} \mathrm{O}_{\text {diatom }}$ record is $3.6 \%$ (pre AD 1200), it is likely that temperature is not 500 the main driver of this isotopic signal, compared to changing source of precipitation. The relatively 501 high values around $A D$ 300, AD 650 and from $A D$ 950-1100 likely suggest summer precipitation 502 (south westerly sources) dominated compared to winter Arctic precipitation. Conversely, around AD $503540, A D 930$ and AD 1150, winter precipitation was likely relatively dominant. The sharp peak just 504 after AD 1200, with extremely enriched stable isotopes, can be explained as a period of high evaporation, or higher summer rainfall (with higher $\delta^{18} \mathrm{O}_{\text {diatom }}$ ) and lower winter rainfall (lower

$506 \delta^{18} \mathrm{O}_{\text {diatom }}$ ). In the former scenario of higher evaporation the lake level may have dropped sufficiently

507 to cause the lake to become effectively closed, thus increasing $\delta^{18} \mathrm{O}_{\text {diatom }}$ further by higher

508 evaporation (Leng and Marshall, 2004). The final sample in the $\delta^{18} \mathrm{O}_{\text {diatom }}$ dataset, around AD 1300

509 has the lowest $\delta^{18} \mathrm{O}_{\text {diatom, }}$ and thus is indicative of a shift to relative dominance of winter

510 precipitation compared with summer.

511

512 The $\delta^{18} \mathrm{O}_{\text {diatom }}$ data and interpretation of the sedimentological proxies fits well with the chironomid 513 response (Figure 9). However, it is clear that the transfer function results do not correspond well 514 with the sedimentological data, given they show increased warming between c. AD 1600-1850, 515 when the other proxies suggest enhanced cooling. This is likely related to the increased \%TOC, which 516 typically is associated with increased productivity and warming temperatures (e.g. Velle et al., 2010).

517 However, this relationship between productivity and climate can decouple, as argued in Brooks et al.

518 (2012). It is decoupled in the Icelandic transfer function (Langdon et al., 2008), as \%TOC plots

519 orthogonal to summer temperature. The Langdon et al. (2008) model includes many lowland lakes, 520 where relatively high levels of organic productivity are associated with warmer temperature lakes. 521 Nonetheless, the large increases in \%TOC in Baulárvallavatn, which are likely associated with cooler 522 summers (cf. Geirsdóttir et al., 2009b), does seem to affect the transfer function performance in 523 relation to the presence of a strong secondary gradient (Juggins, 2013), and it is thus not surprising 524 that sensible quantitative results are not generated. There are a number of semi-terrestrial taxa 525 (e.g., Chaetocladius, Limnophyes, Paraphaenocladius/Parametriocnemus and Pseudosmittia) present 526 at various points in the Baulárvallavatn chironomid record which could support the suggestion of 527 increased catchment erosion due to cooler summers and drier winter conditions. These taxa are 528 present in low numbers in the Icelandic training set and have relatively warm temperature optima 529 (Langdon et al., 2008) and may be a factor contributing to the unreliable temperature reconstruction 530 produced using the Icelandic transfer function, while an ecological interpretation (supported by the 
531 PCA analyses) supports the assertion that they are responding to temperature. Despite the problems

532 with transfer functions outlined by Juggins (2013), there is strong evidence that chironomids are

533 sensitive to summer temperatures in Iceland (Caseldine et al., 2003, 2006; Langdon et al., 2008,

534 2011; Holmes et al., 2011) and hence in some lakes provide a valid temperature reconstruction.

535 Axford et al. (2009) argued for a link with August temperatures through a calibration with the

536 Stykkishólmur temperature record based on a relatively small sample of 10 data points. These

537 analyses showed a stronger relationship with mean annual temperature (possibly acting via the

538 effect of ice thickness and melt-out date on chironomid growing season length and emergence

539 date), but August temperatures were reconstructed due to the known relationship between summer

540 air and water temperature and chironomids (Axford et al., 2009). It has not been possible to carry

541 out a similar calibration exercise here, due to chronological uncertainty in the upper sediments, but

542 the variability seen in this record, compared to other independent proxy data from both terrestrial

543 and marine sources (Figure 10), is strongly suggestive of a climate signal, as for instance is also

544 shown in the high altitude site at Mýfluguvatn (Langdon et al., 2011), where there is co-variation

545 between the C-IT and DCA reconstructions. Thus, although not providing a calibrated quantitative

546 record for Baulárvallavatn the PCA record does provide additional faunally-based climate evidence

547 for the last millennium and has a much stronger chronological control in terms of known

548 uncertainties, than at any other Icelandic site that covers the last 1000 years. Clear periods of long-

549 term trends can be identified within the last 1000 years within the chironomid and other records

550 (Figure 10; inferring climate (summer temperature) from the chironomid PCA analyses), and group

551 broadly into four main phases:

552

553 AD 1020-1310

554 By comparison with the mid- to late $20^{\text {th }}$ century it seems likely that temperatures were slightly 555 warmer in general during this period. The highest temperatures were seen as an isolated peak 556 around AD 1060 with cooling to a clear trough between AD 1130 and AD 1180. The first half of the

$55713^{\text {th }}$ century was warm, comparable to the end of the $20^{\text {th }}$ century, before a second dip after $A D$

5581260 reaching a minimum around AD 1300. In summary the mean values between $A D 1020$ and $A D$

5591310 could be interpreted as warmer than the overall $20^{\text {th }}$ century mean with two, possibly three

560 phases of decadal cooling centred on C. AD 1060-70, AD 1140-80 and AD 1270-1310.

563 Values are relatively stable between AD 1310 and AD 1510, cooler than in the preceding period, but 564 still notably warmer that the second half of the millennium. The period ends though with a sharp 
decline to the second lowest values in the record centred on AD 1535 before returning to values seen in the rest of the period at c. AD 1555.

From AD 1560 the PCA record suggests a consistent decline in temperatures to a minimum around AD 1780 with the lowest temperatures in the record. There is no evidence of any even short-term return to those temperatures preceding $A D 1560$, with the coldest phase being marked between $A D$ 1680-1810.

573

AD 1810 - late $20^{\text {th }}$ century

Apart from an early single peak around AD 1815 values are generally lower than before AD 1560, although warmer than in the preceding two centuries. The trend from c. AD 1900 onwards is for rising temperatures with variability between samples comparable to those throughout the record. By the most recent sample, representing the end of the $20^{\text {th }}$ century and the beginning of the $21^{\text {st }}$ century, values rise to those found almost a thousand years previously.

When the full range of chronological uncertainty is considered the four phases of climatic conditions are still valid (Figure 8), and it is clear that the first half of the millennium experienced warmer climatic conditions than the second half, though with a return to the warmer climate occurring in the last c. 100 years. Comparison of existing records with other terrestrial data and especially offshore data reveal broad scale agreements (Figure 10). Axford et al. (2011) showed significant correlations across marine records around Iceland, and that sites in the west of Iceland (and offshore) relate strongly to the Irminger Current and North Atlantic Drift over time (Ólafsdóttir et al., 2010). Regional climatic variations across Iceland during the Holocene have been apparent from a number of studies, especially for earlier in the Holocene (Caseldine et al., 2006; Axford et al., 2007), and Axford et al. (2011) argue that sites in the north of Iceland may be relatively less coupled to the west, although the nature of the seasonal drivers enhancing this variability over millennial timescales is not clear. The Baulárvallavatn record reinforces some of the broader climate reconstructions for the last millennium: peak warmth in the $11^{\text {th }}$ century $A D$, persisting with decadal variability to the mid- $13^{\text {th }}$ century, a period of cooling in the early $14^{\text {th }}$ century with quite variable but not cold temperatures until a sharp drop c. AD 1535 preceding a more steady decline in temperatures through the $17^{\text {th }}$ and $18^{\text {th }}$ centuries, leading to a minimum around AD 1780-1800. Temperatures begin to recover through the $19^{\text {th }}$ and into the $20^{\text {th }}$ century eventually producing conditions comparable to those at the beginning of the millennium (cf. Miller et al., 2012). 
600 The decadal resolution of the chironomid data appears to clearly capture a low frequency signal with 601 multi-decadal variability superimposed on it and occasional rapid excursions. This low frequency 602 signal compares well with the Haukadalsvatn low frequency signal and as such appears to reflect the 603 orbitally driven decrease in summer insolation for this region (PAGES 2k Consortium, 2013). A clear 604 change is observed around the start of the $13^{\text {th }}$ century, shown by the initiation of a new directional 605 trend in the chironomid PCA reconstruction, which correlates with a change in magnetic 606 susceptibility and sedimentary proxies around AD 1210. The reconstructed cooling c. AD 1270-1310 607 coincides with a period of decreased summer temperature and increased ice growth (AD 1275-1300) 608 in Arctic Canada (Miller et al., 2012), and the beginning of a period of increased varve thickness in 609 Hvítárvatn (Larsen et al. 2011), thought to be the result of climatic changes started by a period of 610 explosive volcanism and propagated by sea-ice and ocean feedbacks (Miller et al., 2012). Andrews et 611 al. (2009) observe a major change in marine climate variability at this time, and it could be

612 interpreted as marking the climate system reorganisation and initial decline into climates associated 613 with the Little Ice Age.

614

615 The variability of the chironomid PCA axis 1 scores can be investigated further. Some periods exist of 616 relatively stable conditions with variation around a mean value, while at other times there are 617 relatively rapid shifts in regime between these stable periods, and short term severe 'events' likely 618 to be of sub-decadal duration. In order to examine this further, the PCA reconstruction was 619 smoothed using a negative exponential smoother; the analyses used a polynomial regression and 620 weights were computed from the Gaussian density function (sampling proportion 0.1, polynomial 621 degree 1). To best understand the nature of the variability in the chironomid data, the residuals of 622 the smoothed PCA were analysed through rolling windows of 50 years, 100 years and 200 years. The 623 results of each rolling window test were similar, and the 100 year dataset have been plotted against 624 North Atlantic Oscillation (NAO) variability (Trouet et al. 2009) for the last 1000 years (Figure 11).

625 The chironomid record shows a centennial scale variability that is persistent throughout the whole of 626 the last millennium. This variability is based on the residuals, and so exists on top of the long-term 627 trends noted above. Comparison with the NAO reconstruction from Trouet et al. (2009) shows a 628 clear match between the records (within the errors of the age model), especially between AD 1400629 2000. Before this, the oscillations in the chironomids pervade, while the NAO index shows a period 630 of relatively less variability but was in a phase of enhanced dominant mode. Interestingly the 631 magnitude of the variability of the chironomids is relatively large, and increasing from AD 10006321650 , but thereafter reduced in magnitude. The phase of positive NAO is linked to enhanced zonal 
633 flow, with westerlies delivering warmer weather to continental Europe, with the storm track moving

634 further north and so Iceland is warmer but wetter in winter. In more negative phases of the NAO sea

635 ice builds up around Iceland so it is cooler but drier. A wetter winter will likely increase snowfall

636 around Baulárvallavatn, which would be melted off in warmer summers, influencing chironomid

637 populations which typically respond to summer temperatures. Thus, the controls of NAO on

638 Icelandic temperature seem to match the variability of the chironomid faunas on a multi-decadal to

639 centennial scale. Other links have been made between NAO and aquatic ecosystems (e.g. Straile,

640 2002; Blenckner et al. 2007), with the dominant argument being for a link through food-webs

641 primarily controlled by faster population growth of algae in warmer waters. The peaks and troughs

642 in NAO at the multi-decadal scale (i.e. warmer/cooler climate) clearly relate to enhanced variability

643 of chironomid communities, suggesting that as the food-web is altered through NAO driven

644 mechanisms, the chironomids also respond in terms of relatively high levels of internal trophic level

645 variability.

646

647 Wider significance and broader issues

648 Examination of the Baulárvallavatn record, especially in comparison with the other available

649 Icelandic terrestrial data (Figure 10), raises a number of issues concerning how best to derive the

650 desired quantitative high resolution terrestrial temperature record that is really needed to compare

651 with onshore and offshore records elsewhere. It seems likely that at present chironomid-based

652 temperature reconstructions provide the best opportunity for calibrated quantitative data but it is

653 not clear whether a transfer function or calibrated PCA/DCA approach offers the best route (e.g.,

654 Velle et al., 2010; Brooks et al., 2012; Juggins, 2013; Berntsson et al., 2014). For some lakes the C-IT

655 training set based methodology, however the training set is derived (Holmes et al., 2011), does not

656 appear to be able to reflect likely real temperature changes. Looking for variability in the

657 palaeorecord using PCA/DCA seems to be more appropriate, though it is reliant on accurate and

658 precise chronologies. Alternatively, in some lakes the secondary gradients may be too strong to rely

659 overly on transfer function derived C-IT (Berntsson et al., 2014). If it is assumed that such faunal

660 approaches are the optimal choice then the pressing need is to establish the types of lakes that are

661 best suited. It may be that smaller, higher lakes are more sensitive to temperature change (e.g.

662 Langdon et al. 2011), as they are relatively buffered against human impact. Low altitude, large and

663 deep lakes such as Haukadalsvatn (Geirsdóttir et al., 2009b) and Lögurinn (Striberger et al., 2012)

664 offer important opportunities for proxies such as BSi and \%TOC but calibration to temperature may

665 prove difficult, as human activities are likely to impact these proxies, although in the latter case the

666 presence of a chironomid fauna may eventually prove to provide a suitable temperature record. 
667 Smaller lakes at relatively low altitudes have been shown to provide sensitive C-IT reconstructions, 668 despite the possible influence of settlement (e.g. Holmes, 2008; Gathorne-Hardy et al. 2009). It

669 remains to be seen whether high productivity (hence relatively high sample resolution), air

670 temperature sensitive lakes can be found at high enough altitudes to meet the necessary criteria. As

671 such the approach followed at Baulárvallavatn offers a promising opportunity for further

672 development at sites with comparable or better dating control, and for which a well developed

673 quantitative recent record would provide the sort of robust calibration required to produce a high

674 quality temperature reconstruction. The challenge remains to produce the sort of high resolution

675 calibrated data set for temperature that both offshore records and modelling studies merit but it is

676 only by the detailed analysis of sites considered potentially suitable that the most valuable records

677 will be discovered.

678

679

680 Acknowledgements

681 We would like to thank Gareth Thompson for help in the field and with preparing the diatom stable 682 isotope samples and running the sedimentological analyses. Hilary Sloane, Carol Arrowsmith and

683 Chris Kendrick are thanked for running the stable isotope analysis. We thank Tomasz Goslar for

684 discussion with the interpretation of radiocarbon dates. Andrew Parnell is thanked for his help with 685 the R package Bchron, particulary Bchronproxyplot. Helen Ward and Gareth James are thanked for 686 preparing the tephra samples for microprobe analysis. Chris Hayward at the Tephra Analytical Unit, 687 University of Edinburgh is thanked for help with tephra analyses. We are very grateful to Sigurður 688 Steinpórsson for his unpublished analyses on the Ljósufjöll system from the geochemical data base 689 at Science Institute, analyst Niels Oskarsson. The Southampton Cartographic unit is thanked for 690 preparing the figures.

691

\section{Funding}

693 The work described in this manuscript was undertaken through the MILLENNIUM project, which

694 focused on better understanding the European climate of the last Millennium. The project was

695 funded by the EU through FP6. We thank the funders, but also the project PI, Danny McCarroll, as

696 well as the WP3 leader Sheila Hicks, plus all colleagues who worked under the Millennium project for 697 stimulating and fruitful scientific discussion. 
700 Andrews JT, Darby D, Eberle D et al. (2009) A robust, multisite Holocene history of drift ice off 701 northern Iceland: implications for North Atlantic climate. The Holocene 19: 71-77.

702 Axford Y, Miller GH, Geirsdóttir, Á et al. (2007) Holocene temperature history of northern Iceland 703 inferred from subfossil midges. Quaternary Science Reviews 26: 3344-3358.

704 Axford Y, Geirsdóttir Á, Miller GH et al. (2009) Climate of the Little Ice Age and the past 2000 years in northeast Iceland inferred from chironomids and other lake sediment proxies. Journal of

706 Paleolimnology 41: 7-24.

707 Axford Y, Andresen CS, Andrews JT et al. (2011) Do paleoclimate proxies agree? A test comparing 19

708 late Holocene climate and sea-ice reconstructions from Icelandic marine and lake sediments.

709 Journal of Quaternary Science 26: 645-656.

710 Berntsson A, Rosqvist GC and Velle G (2014) Late-Holocene temperature and precipitation changes

711 in Vindelfjällen, mid-western Swedish Lapland, inferred from chironomid and geochemical data. The

712 Holocene 24: 78-92.

713 Björnsson H (2003) The annual cycle of temperature in Iceland: the 1961-1990 average. Technical

714 Report, Icelandic Meteorology Office.

715 Boygle JE (1999) Variability of tephra in lake sediments, Svinavatn, Iceland. Global and Planetary

716 Change 435: 129-149.

717 Blenckner T, Adrian R, Livingstone DM et al. (2007) Large-scale climatic signatures in lakes across

718 Europe: a meta-analysis. Global Change Biology 13: 1314-1326.

719 Brooks SJ, Langdon PG and Heiri O (2007) The Identification and Use of Palaearctic Chironomidae 720 Larvae in Palaeoecology. QRA Technical Guide No. 10. Quaternary Research Association, London.

721 Brooks SJ, Axford Y, Heiri O et al. (2012) Chironomids can be reliable proxies for Holocene

722 temperatures: A comment on Velle et al. (2010). The Holocene 22: 1495-1500.

723 Caseldine CJ, Geirsdóttir Á and Langdon PG (2003) Efstadalsvatn - a multi-proxy study of a Holocene 724 lacustrine sequence from NW Iceland. Journal of Paleolimnology 30: 55-73.

725 Caseldine CJ, Langdon PG and Holmes N (2006) Early Holocene climate variability and the timing and 726 extent of the Holocene thermal maximum (HTM) in northern Iceland. Quaternary Science Reviews $727 \quad 25: 2314-2331$.

728 Chawchai S, Kylander M, Chabangborn A, et al. (submitted) An example of commonly used XRF core 729 scanning based proxies for organic rich lake sediments and peat. The Holocene

730 Clayton RN and Mayeda TK (1963) The use of bromine pentafluoride in the extraction of oxygen 731 from oxides and silicates for isotopic analysis. Geochimica et Cosmochimica Acta 27: 43-52. 
732 Croudace I, Rindby A and Rothwell R (2006) ITRAX: description and evaluation of a new multi

733 function X-ray core scanner. In: Rothwell RG (ed) New techniques in sediment core analysis:

734 Geological Society London Special Publication 267, pp. 51-63.

735 Cunningham L, Austin WEN, Knudsen KL et al. (2013) Reconstructions of surface ocean conditions

736 from the northeast Atlantic and Nordic seas during the last millennium. The Holocene 23: 921-935.

737 Dearing JA (1994) Environmental Magnetic Susceptibility. Chi Publishing, Kenilworth.

738 Dugmore AJ, Larsen G, Newton AJ (1995) Seven tephra isochrones in Scotland. The Holocene 5: 257-

739266.

740 Esper J, Büntgen U, Timonen M et al. (2012) Variability and Extremes of Northern Scandinavian

741 summer temperatures over the Past Two Millennia. Global and Planetary Change 88-89: 1-9.

742 Gathorne-Hardy FJ, Erlendsson E, Langdon PG et al. (2009) Lake sediment evidence for late-Holocene

743 climate change and landscape erosion in western Iceland. Journal of Paleolimnology 42: 413-426.

744 Geirsdóttir Á, Miller GH, Axford A et al. (2009a) Holocene and latest Pleistocene climate and glacier

745 fluctuations in Iceland. Quaternary Science Reviews 28: 2107-2118.

746 Geirsdóttir Á, Miller GH, Thordarson T et al. (2009b) A 2000 year record of climate variations

747 reconstructed from Haukadalsvatn, West Iceland. Journal of Paleolimnology 41: 95115.

748 Grönvold K, Óskarsson K, Johnsen SJ et al. (1995) Tephra layers from Iceland in the Greenland GRIP

749 ice core correlated with oceanic and land sediments. Earth and Planetary Science Letters 135: 149-

750155.

751 Gudmundsdóttir, ER, Larsen, G, Eiríksson, J (2012) Tephra stratigraphy of the North Icelandic shelf:

752 extending tephrochronology into marine sediment off North Iceland. Boreas 41, 719-734.

753 Haslett J and Parnell AC (2008) A simple monotone process with application to radiocarbon-dated

754 depth chronologies. Journal of the Royal Statistical Society: Series C (Applied Statistics) 57: 399-418.

755 Hayward CL (2012) High Spatial Resolution Electron Probe Microanalysis of Tephras and Melt

756 Inclusions without beam-induced chemical modification. The Holocene 22: 119-125.

757 Hofmann W (1971) Zur Taxonomie und Palökologie subfossiler Chironomiden (Dipt.) in

758 Seesedimenten. Ergebnisse der Limnologie, Archiv für Hydrobiologie Beiheft (International

759 Vereinigung für theoretische und angewandte Limnologie, Stuttgart) 6: 1-50.

760 Holmes N (2008) Validation of chironomid-inferred temperature reconstructions in Iceland: the

761 potential for reconstructing quantitative changes in Holocene climate. Geographica Helvetica 63: 4-

76214.

763 Holmes N, Langdon PG and Caseldine CJ (2009) Subfossil chironomid variability in surface sediment

764 samples from Icelandic lakes: implications for the development and use of training sets. Journal of

765 Paleolimnology 42: 281-295. 
766

767

768

769

770

771

772

773

774

775

776

777

778

779

780

781

782

783

784

785

786

787

788

789

790

791

792

793

794

795

796

797

798

799

Holmes N, Langdon PG, Caseldine CJ et al. (2011) Merging chironomid training sets: implications for palaeoclimate reconstruction. Quaternary Science Reviews 30: 2793-2804.

Jóhannesson H, Flores R and Jónsson J (1981) A short account on the Holocene tephrochronology of the Snæfellsjökull volcano, Western Iceland. Jökull 31: 23-30.

Johnson TC, Brown ET and Shi J (2011) Biogenic silica deposition in Lake Malawi, East Africa over the past 150,000 years. Palaeogeography, Palaeoclimatology, Palaeoecology 303: 103-109.

Juggins S (2007) C2 User guide. Software for ecological and palaeoecological data analysis and visualisation. University of Newcastle, UK.

Juggins S (2013) Quantitative reconstructions in palaeolimnology: new paradigm or sick science?

Quaternary Science Reviews 64: 20-32.

Juillet-Leclerc A. and Labeyrie L (1987) Temperature dependence of the oxygen isotopic

fractionation between diatom silica and water. Earth and Planetary Science Letters 84: 69-74.

Kaufman DS, Schneider DP, McKay NP et al. (2009) Recent Warming Reverses Long-Term Arctic

Cooling. Science 325: 1236-1239.

Kokfelt TF, Hoernle K, Lundstrom C et al. (2009) Time-scales for magmatic differentiation at the Snaefellsjokull central volcano, western Iceland: Constraints from U-Th-Pa-Ra disequilibria in postglacial lavas. Geochimica et Cosmochimica Acta 73: 1120-1144.

Kylander ME, Lind EM, Wastegård S et al. (2012) Recommendations for using XRF core scanning as a tool in tephrochronology. The Holocene 22: 371-375.

Lang B, Bedford AP, Richardson N et al. (2003) The use of ultra-sound in the preparation of carbonate and clay sediments for chironomid analysis. Journal of Paleolimnology 30: 451-460.

Langdon PG, Holmes N and Caseldine CJ (2008) Environmental controls on modern chironomid faunas from NW Iceland and implications for reconstructing climate change. Journal of Paleolimnology 40: 273-293

Langdon PG, Leng MJ, Holmes N et al. (2010) Lacustrine evidence of early-Holocene environmental changes in northern Iceland: a multiproxy palaeoecology and stable isotope study. The Holocene 20: 205-214.

Langdon PG, Caseldine CJ, Croudace IW et al. (2011) A chironomid-based reconstruction of summer temperatures in NW Iceland since AD 1650. Quaternary Research 75: 451-460.

Larsen G, Newton A, Dugmore A et al. (2001) Geochemistry, dispersal, volumes and chronology of Holocene silicic tephra layers from the Katla volcanic system, Iceland. Journal of Quaternary Science 16: 119-132.

Larsen G, Eiríksson J, Knudsen K et al. (2002) Correlation of Late Holocene terrestrial and marine tephra markers, north Iceland: implications for reservoir age changes. Polar Research 21: 283-290. 
800 Larsen G and Eiríksson J (2008) Late Quaternary terrestrial tephrochronology of Iceland - frequency

801 of explosive eruptions, type and volume of tephra deposits. Journal of Quaternary Science 23: 109-

802120.

803 Larsen G, Eiríksson J and Gudmundsdóttir ER (2014) Last millennium dispersal of air-fall tephra and 804 ocean-rafted pumice towards the north Icelandic shelf and the Nordic seas. In Austin WEN, Abbott

805 PM, Davies SM et al. (eds) Marine tephrochronology. Geological Society of London, Special

806 Publications 398: 113-140

807 Larsen DJ, Miller GH, Geirsdóttir Á et al. (2011) A 3000-year varved record of glacier activity and

808 climate change from the proglacial lake Hvítárvatn, Iceland. Quaternary Science Reviews 30: 2715-

8092731.

810 Larsen DJ, Miller GH, Geirsdóttir Á et al. (2012) Non-linear Holocene climate evolution in the North

811 Atlantic: a high-resolution, multi-proxy record of glacier activity and environmental change from

812 Hvítárvatn, central Iceland. Quaternary Science Reviews 39: 14-25.

813 Lawson IT, Gathorne-Hardy FJ, Church MJ et al. (2007) Environmental impacts of the Norse

814 settlement: palaeoenvironmental data from Myvatnssveit, northern Iceland. Boreas 36: 1-19.

815 Leng MJ and Marshall JD (2004) Palaeoclimate interpretation of stable isotope data from lake

816 sediment archives. Quaternary Science Reviews 23: 811-831.

817 Leng MJ and Sloane HJ (2008) Combined oxygen and silicon isotope analysis of biogenic silica.

818 Journal of Quaternary Science 23: 313-319.

819 Liu X, Colman SM, Brown ET et al. (2013) Estimation of carbonate, total organic carbon, and biogenic 820 silica content by FTIR and XRF techniques in lacustrine sediments. Journal of Paleolimnology 50: 387821398.

822 Massé G, Rowland SJ, Sicre M-A et al. (2008) Abrupt climate changes for Iceland during the last

823 millennium: evidence from high resolution sea ice reconstructions. Earth and Planetary Science

824 Letters 269: 565-569.

825 McGovern TH, Vésteinsson O, Friđriksson A et al. (2007) Landscapes of settlement in northern

826 Iceland: historical ecology of human impact and climate fluctuation on the millennial scale.

827 American Anthropologist 109: 27-51.

828 Meyers PA and Teranes JL (2001) Sediment organic matter. In Last WM and Smol JP (eds) Tracking

829 environmental change using lake sediments. Volume 2: physical and geochemical techniques. Kluwer

830 Academic Publishers, pp. 239-69.

831 Miller GH, Geirsdóttir Á, Zhong Y et al. (2012) Abrupt onset of the Little Ice Age triggered by

832 volcanism and sustained by sea-ice /ocean feedbacks. Geophysical Research Letters 39: L02708. 
833 Morley DW, Leng MJ, Mackay AW et al. (2004) Cleaning of lake sediment samples for diatom oxygen 834 isotope analysis. Journal of Paleolimnology 31: 391-401.

835 Ólafsdóttir S, Jennings AE, Geirsdóttir Á et al. (2010) Holocene variability of the North Atlantic 836 Irminger Current on the south- and northwest shelf of Iceland. Marine Micropaleontology 77: 101837118.

838 Ólafsdóttir S, Geirsdóttir Á, Miller GH et al. (2013) Synchronizing Holocene lacustrine and marine 839 sediment records using paleomagnetic secular variation. Geology 41: 535-538.

840 PAGES 2k Consortium (2013) Continental-scale temperature variability during the past two 841 millennia. Nature Geoscience 6: 339-346.

842 Pilcher JR, Hall VA and McCormac FG (1996) An outline tephrochronology for the Holocene of the 843 north of Ireland. Journal of Quaternary Science 11: 485-494.

844 Rieradevall M and Brooks SJ (2001) An identification guide to subfossil Tanypodinae larvae (Insecta:

845 Diptera: Chironomidae) based on cephalic setation. Journal of Paleolimnology 25: 81-99.

846 Rosqvist GC, Leng MJ, Goslar T et al. (2013) Shifts in precipitation during the last millennium in

847 northern Scandinavia from lacustrine isotope records. Quaternary Science Reviews 66: 22-34.

848 Schillereff DN, Chiverrell RC, Macdonald N et al. (2014) Flood stratigraphies in lake sediments: A 849 review. Earth-Science Reviews 135: 17-37.

850 Schmid PE (1993) A key to the larval Chironomidae and their instars from Austrian Danube region 851 streams and rivers. Part 1: Diamesinae, Prodiamesinae and Orthocladiinae. Wasser und Abwasser 852 Supplementband 3/93: 1-513.

853 Sicre M-A, Hall IR, Mignot J et al. (2011) Sea surface temperature variability in the subpolar Atlantic 854 over the last two millennia. Paleooceanography 26: PA4218.

855 Simpson I, Gudmundsson G, Thomson AM et al. (2004) Assessing the role of winter grazing in historic 856 land degradation, Myvatnssveit, northeast Iceland. Geoarchaeology 19: 471-502.

857 St. Amour NA, Hammarlund D, Edwards TWD et al. (2010) New insights into Holocene atmospheric 858 circulation dynamics in central Scandinavia inferred from oxygen-isotope records of lake-sediment 859 cellulose. Boreas 39: 770-782.

860 Straile D (2002) North Atlantic Oscillation synchronizes food-web interactions in central European

861 Lakes. Proceedings of the Royal Society of London, Series B 269: 391-395.

862 Striberger J, Björck S, Holmgren S et al. (2012) The sediments of Lake Lögurinn - A unique proxy 863 record of Holocene glacial meltwater variability in eastern Iceland. Quaternary Science Reviews 38: $864 \quad 76-88$. 
865 ter Braak CJF and Šmilauer P (2002) CANOCO Reference Manual and CanoDraw for Windows User's 866 Guide: Software for Canonical Community Ordination (version 4.5). Microcomputer Power, New 867 York.

868 Thorarinsson, S. (1967) The eruptions of Hekla in historical times. The eruption of Hekla 1947-1948.

869 Volume 1. Societas Scientiarum Islandica: 1-183.

870 Thordarsson T and Höskuldsson Á (2008) Postglacial volcanism on Iceland. Jökull 58: 197-228.

871 Trouet V, Esper J, Graham NE et al. (2009) Persistent positive North Atlantic oscillation mode 872 dominated the Medieval Climate Anomaly. Science 324: 78-80.

873 Turney CSM (1998) Extraction of rhyolitic component of Vedde microtephra from minerogenic lake 874 sediments. Journal of Paleolimnology 19: 199-206.

875 Velle G, Brodersen KP, Birks HJB et al. (2010) Midges as quantitative temperature indicator species:

876 Lessons for palaeoecology. The Holocene 20: 989-1002.

877 Wiederholm T (ed) (1983) Chironomidae of the Holarctic region. Keys and diagnoses. Part I. Larvae. 878 Entomologica Scandinavica Supplement 19: 1-457.

879 
Figure 1: Location map of Baulárvallavatn (1a) and bathymetry, showing the coring location (1b).

882

883

Figure 2: X-radiograph and Itrax data. All elemental data are divided by the counts (kcps) and the relative smoothing of the data are shown. The geochemical data do not reveal any clear variations that can be linked to climate effects owing to the largely monolithic composition of catchment material (weathered basalt). They are successful, however, in identifying likely ash horizons, as shown by changes in the X-radiograph and associated oscillations in associated elements. Note the large spikes in K towards the base of the sequence, which represent the Landnám and Sn-1 tephras (see Table 2).

890

Figure 3: (a) Landnam vs SN-1 tephra plots; (b) Baulárvallavatn 23-24 cm (Hekla geochemistry) vs Hekla 1510 and Loch Portain B.

893

Figure 4: Chronological model produced in Bchron. Coring date, ${ }^{137} \mathrm{Cs}$ (1963) date and tephra dates (Table 2) were input. The plot shows the mean chronology and the $95 \%$ confidence limits (grey shaded areas).

897

898

Figure 5: Sedimentological and isotope data. a) sediment \%TOC; b) sediment $\delta^{13} \mathrm{C}$; c) sediment $\mathrm{C} / \mathrm{N}$;

d) low frequency magnetic susceptibility; e) frequency dependent susceptibility; f) diatom $\delta^{18} \mathrm{O}$.

900

901 Figure 6: Modern day isotopic composition of Baulárvallavatn and nearby lakes. The black filled circles represent a range of samples taken in April/May 2007 (end of winter) from lakes on the Snæfellsnes peninsula. Catchment sampling locations included lake inflows and outflows, snow beds and peat water inflows. The black filled squares are lake waters from Baulárvallavatn and Svínavatn, sampled in April 2006. The open diamonds reflect lake water samples taken in July 2007 (summer), and show that while most lakes plot on or near to the GMWL, two lakes (Saurarvatn and Svínavatn) plot away from the GMWL, suggesting they can be relatively evaporative in the summer. Baulárvallavatn summer water samples plot on the GMWL.

909

910 Figure 7: Baulárvallavatn chironomid percentage data (selected taxa); Chironomid-inferred

911 temperature reconstructions, and PCA axis 1 scores. 
913 Figure 8: Chironomid PCA axis 1 score reconstruction. Reconstruction using mean chronology is in

914 black. Reconstructions using 1000 sample chronologies are in grey.

915

916 Figure 9: Composite diagram, comparing the chironomid results (PCA axis 1 reconstruction and \% 917 head capsule concentration) against the organics proxies from BAUL (\%TOC, $\delta^{13} \mathrm{C}$ and $\mathrm{C} / \mathrm{N}$ ) and the 918 diatom $\delta^{18} \mathrm{O}$.

919

920 Figure 10: Composite diagram, showing chironomid results (PCA axis 1 reconstructions) against

921 selected terrestrial and marine proxies from Iceland including Stora Viðarvatn chironomid inferred 922 summer temperature (Axford et al. 2009), Haukadalsvatn BSi (Geirsdottir et al. 2009b), Hvítárvatn

923 ice thickness (Larsen et al. 2011), and offshore alkenone water temperatures (Sicre et al. 2011).

924

925 Figure 11: Comparison of chironomid variability against NAO over the last 1000 years.

926

$927 \quad$ List of Tables

928

929 Table 1. Radiocarbon determinations from the BAUL sequence.

930

931 Table 2. Details of the tephra found in each depth layer investigated. The different volcanic centres

932 are represented by Ka (Katla), Ve (Vei ivötn), Gr (Grímsvötn), Sn (Snæfellsnes) To (Torfajökull)

933 and Hk (Hekla). The numbers in parentheses after each eruption centre relate to the number of

934 shards identified from that centre according to the major element results (see Sup. Material). The

935 tephra in the right hand column represents the most likely eruption ascribed to each depth

936 layer, as discussed in the text. Note, for the 14-15 cm layer, both ages are used in the generation

937 of the age model (Figure 4).

938

939

940 Supplementary Material

941 Excel spreadsheet with detailed geochemical data from each tephra shard analysed under EMPA

942 from the BAUL sequence. 
Fig 1

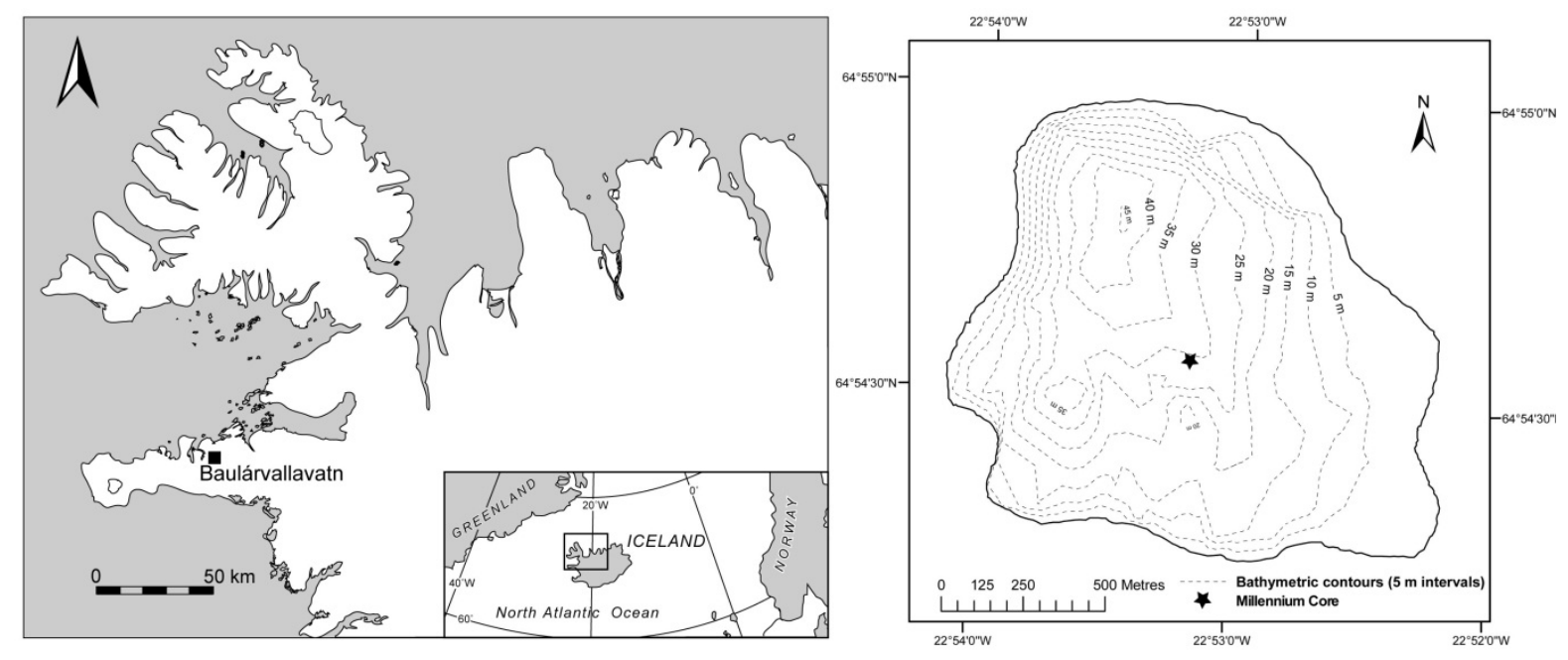


Fig 2

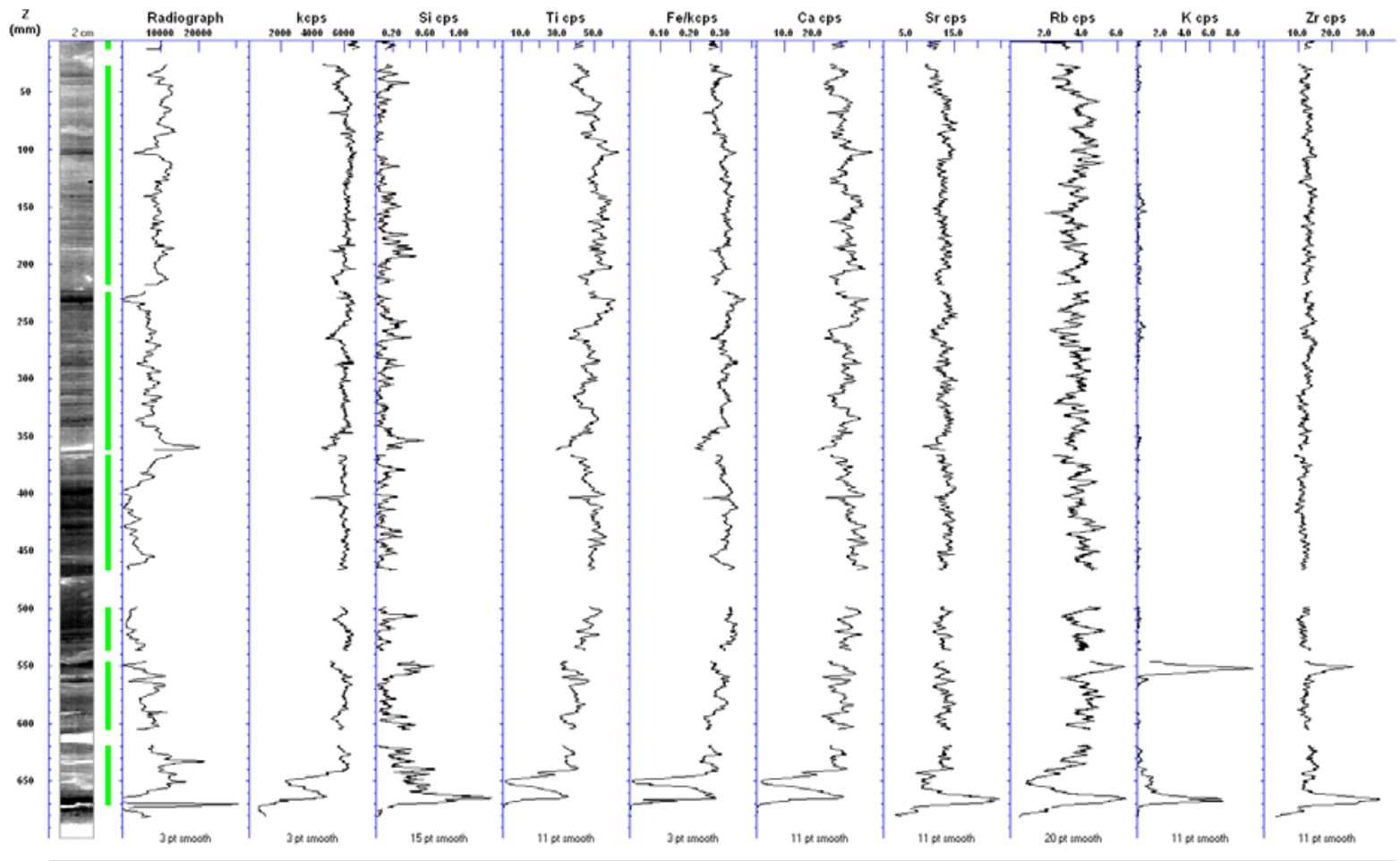

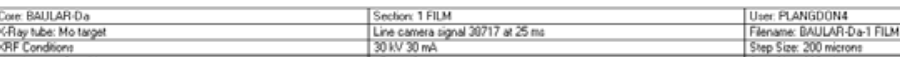


Fig 3

FIG X

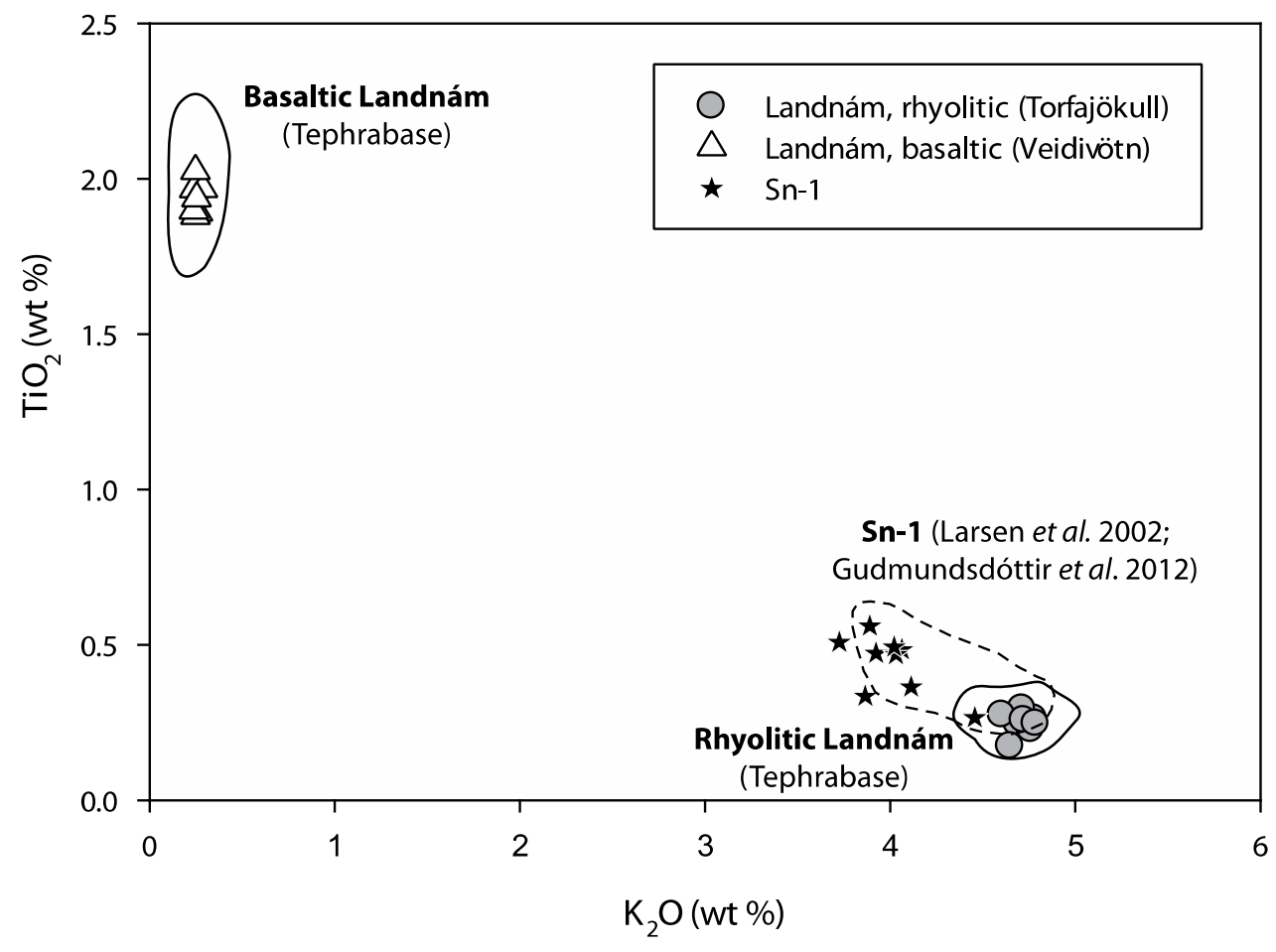

FIG Y

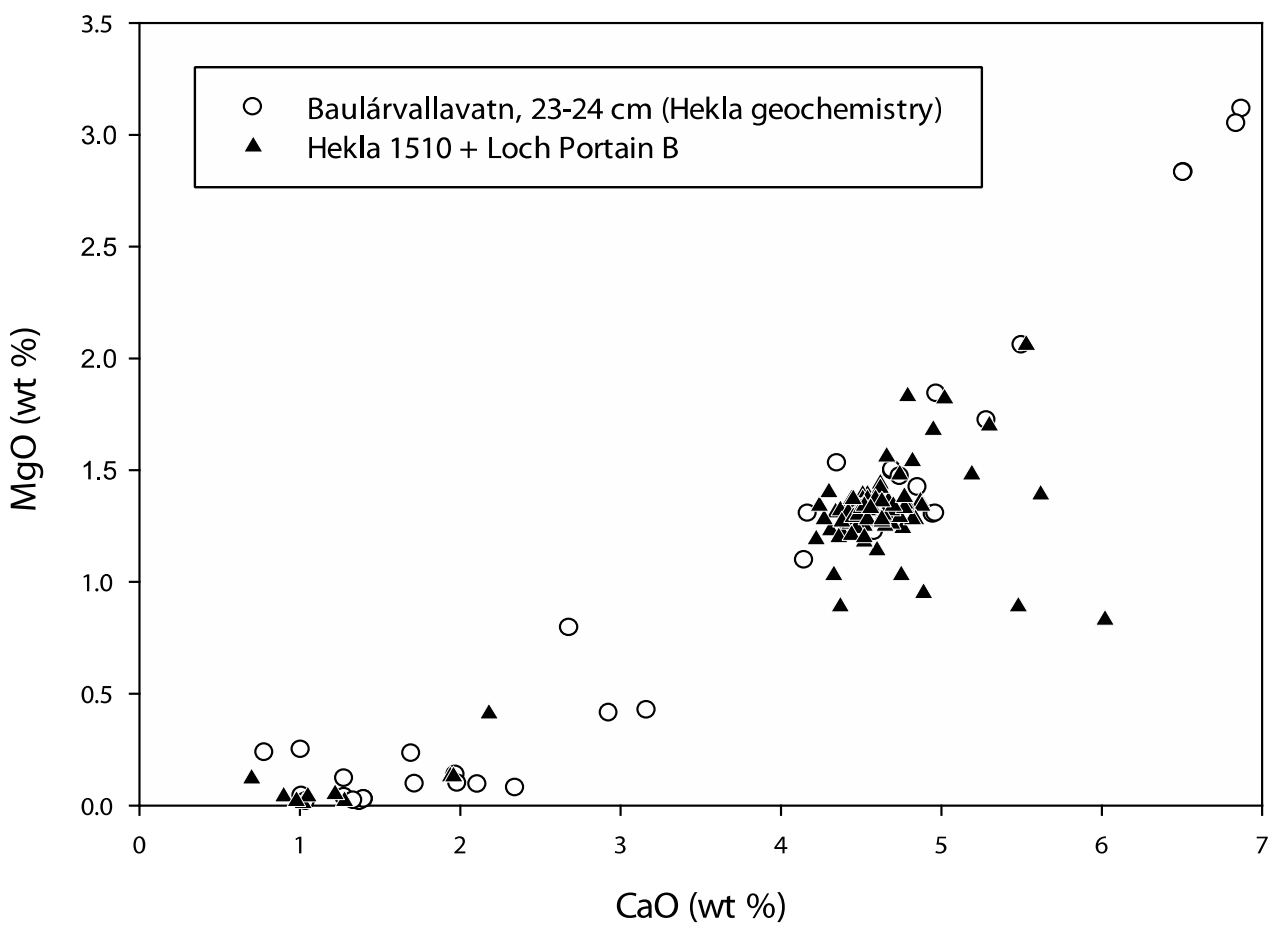


Fig 4

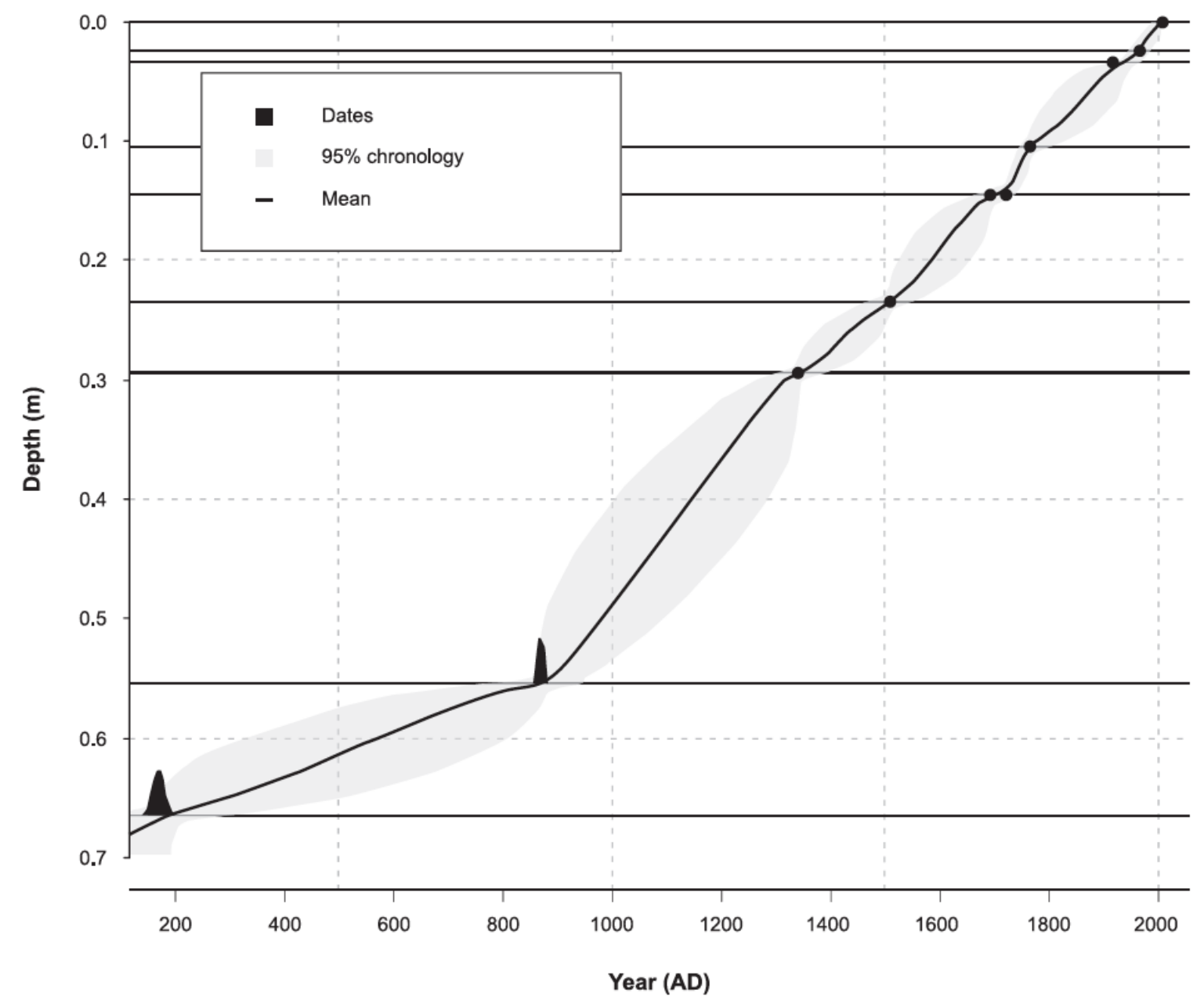




$$
3 Y^{2}
$$




$$
1
$$


Fig 7

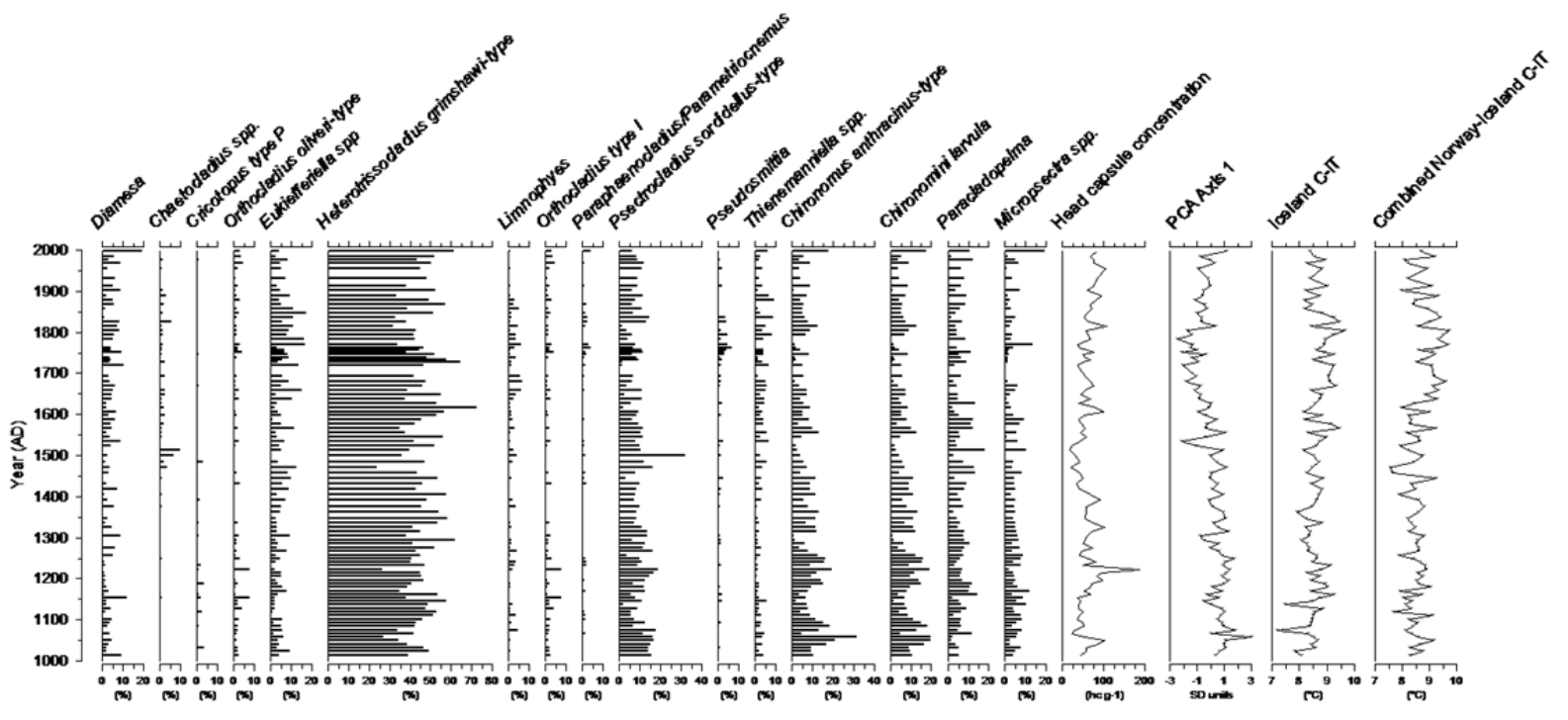


Fig 8

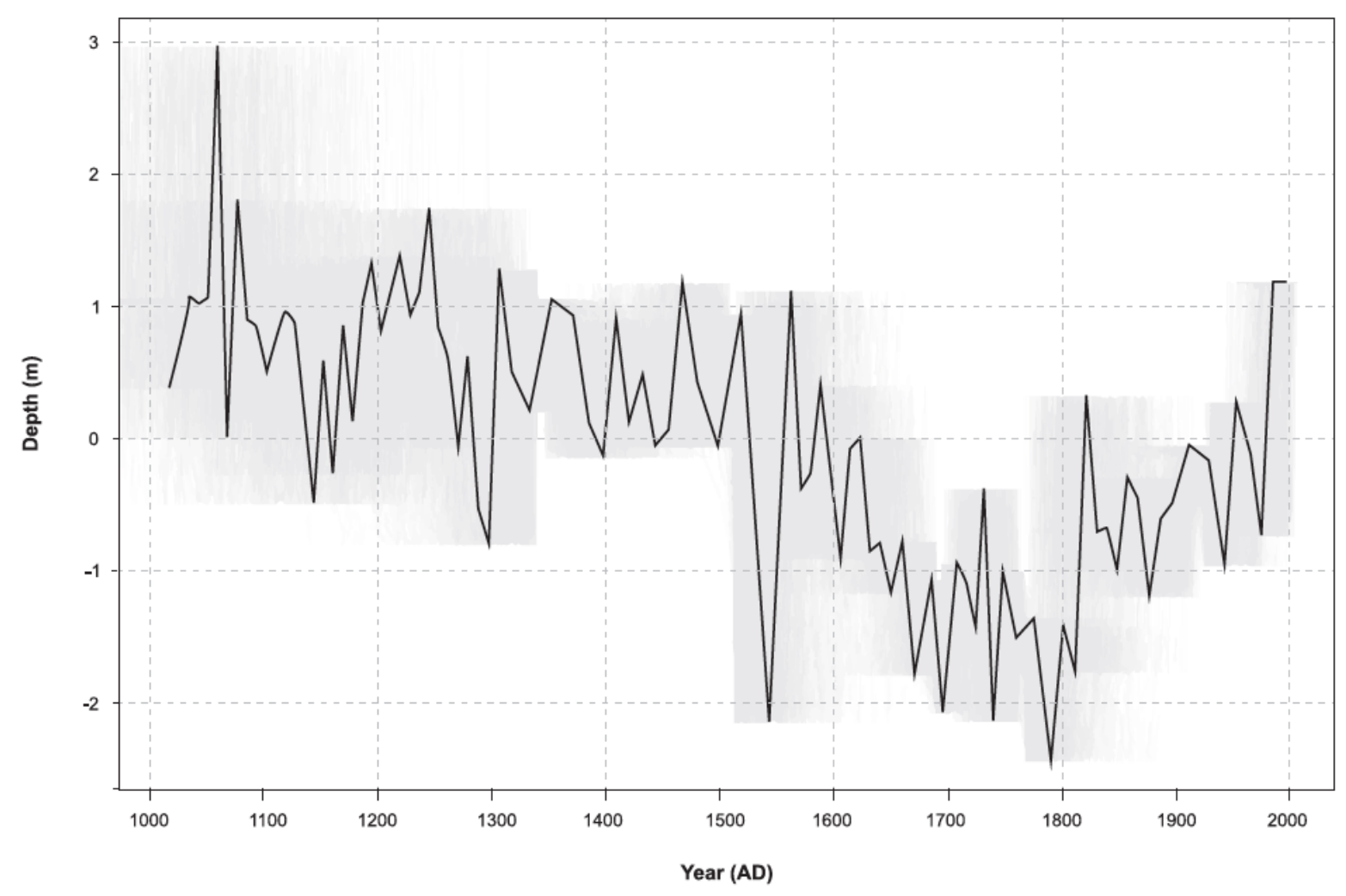


Fig 9

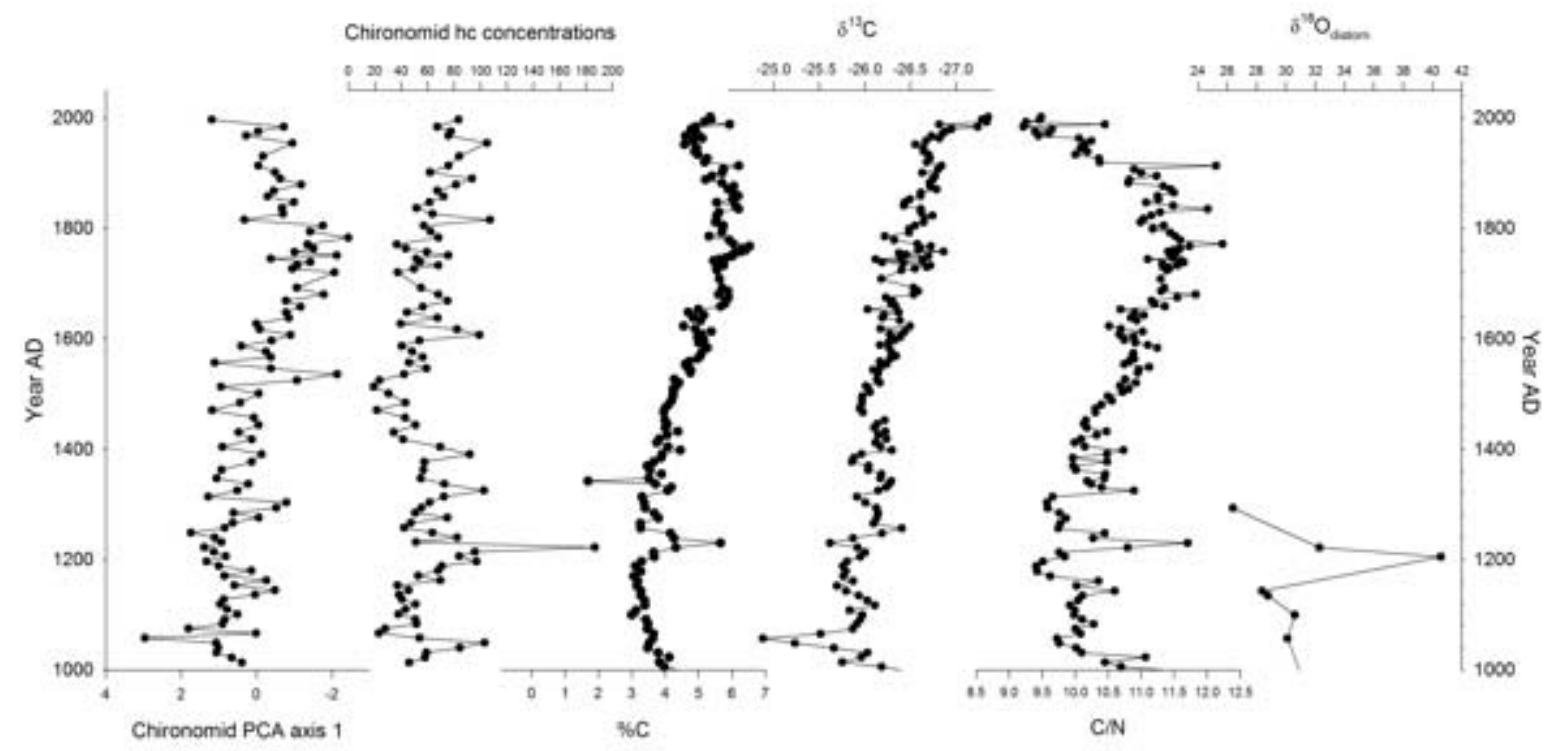


Fig 10

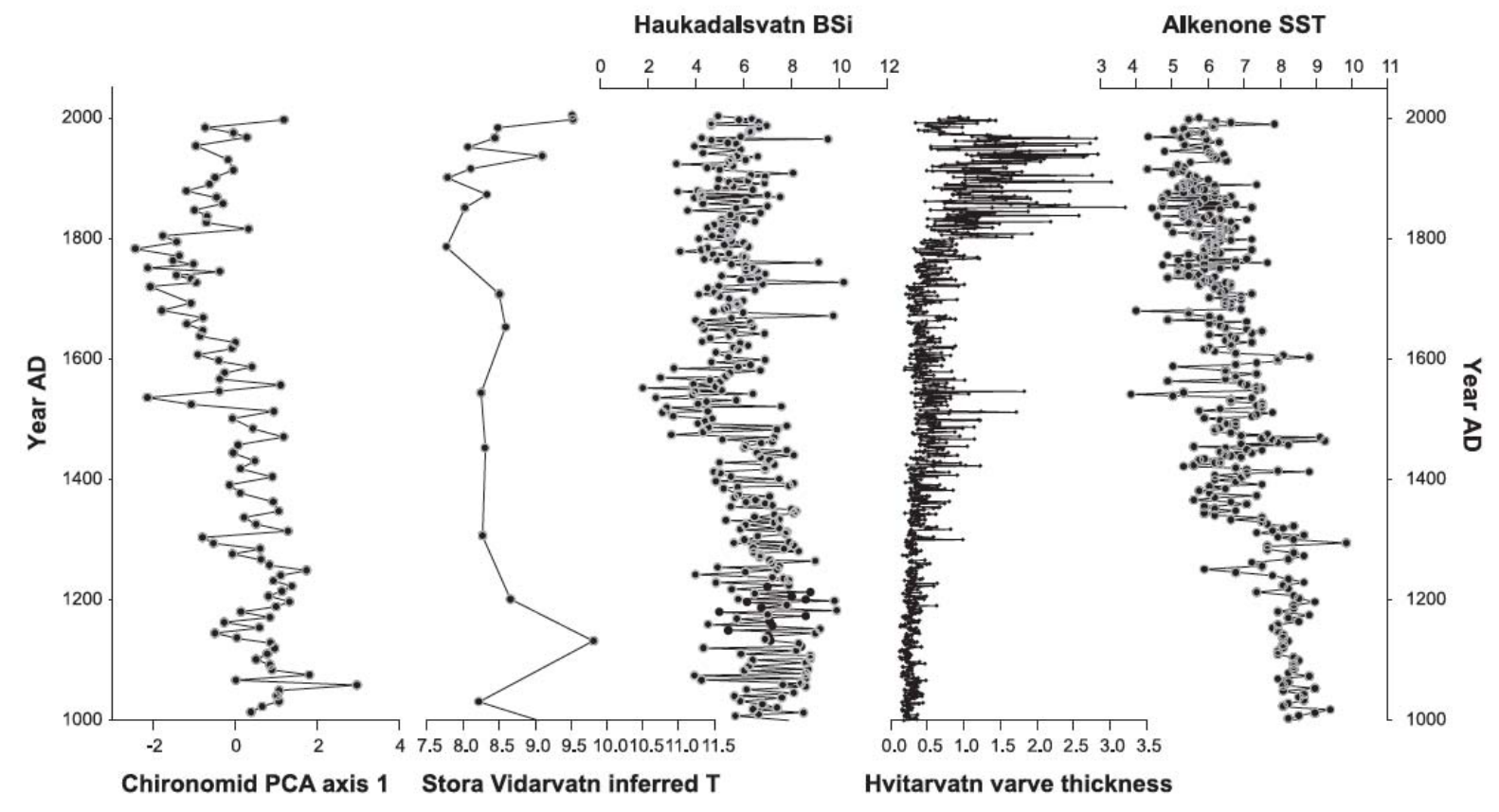


Fig 11

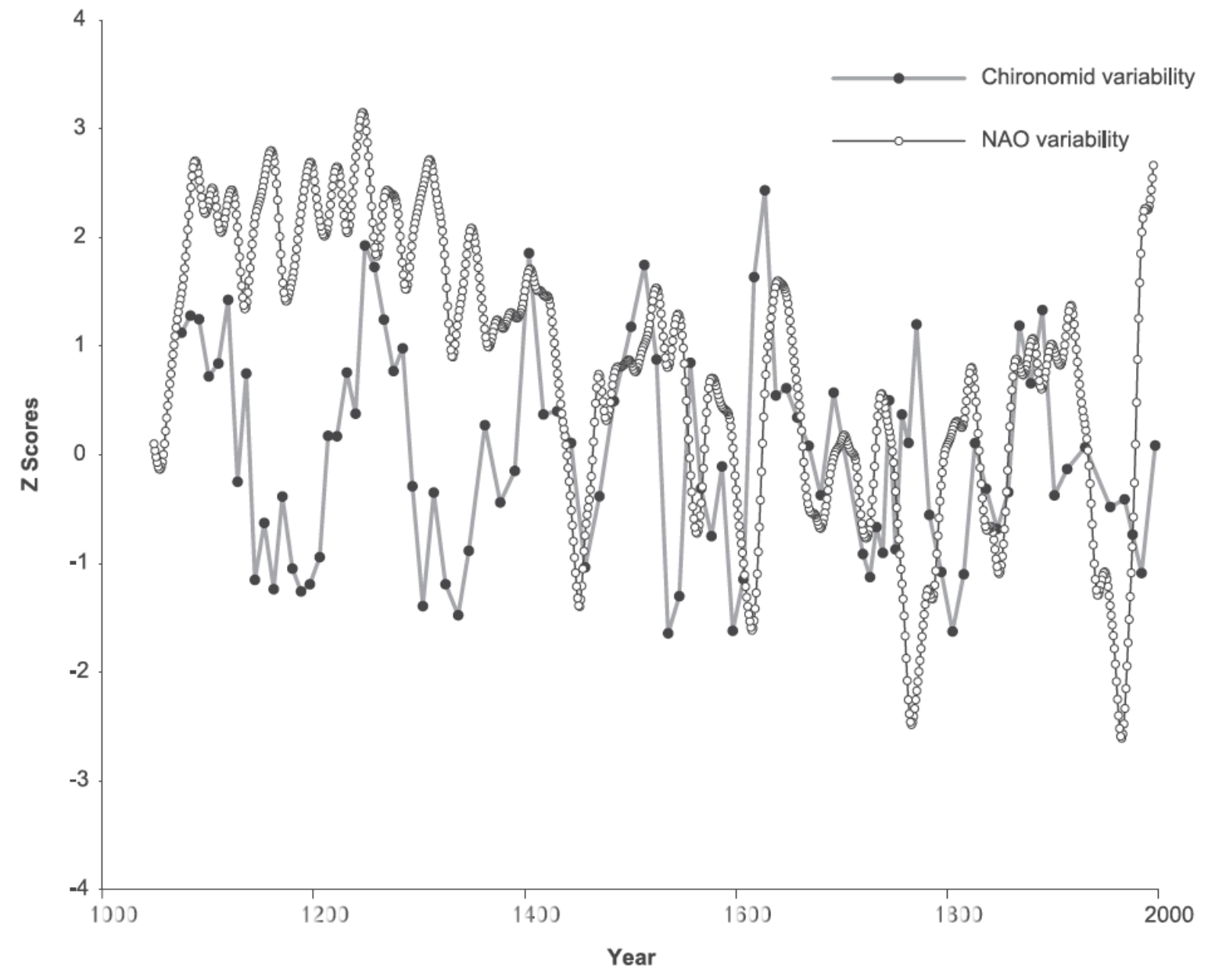

